\title{
Does Value Averaging Strategy Improve Investment Performance? Evidence from the Korean Fund Market ${ }^{*}$
}

\author{
Hyuk Choe, Professor, Seoul National University
}

Ju Il Ban ${ }^{* *}$, Associate Professor, Sangmyung University

\begin{abstract}
$<$ Abstract $>$
This study analyzes whether a value averaging (VA) strategy, which adjusts the amount of investment each period to achieve the target amount of investment in risk assets, as a modified form of a dollar cost averaging (DCA) strategy, improves investment performance. Using 18.5 years of fund market data in Korea from 2001 to June 2019, we compare the investment performance of VA strategy relative to two alternatives: DCA strategy, which invests a certain amount in each period, and Buy-and-Hold (BH) strategy, which refers to half-and-half asset allocation between risky and risk-free assets and has an expected return which is the same as that of DCA in the ex-ante sense. Our historical performance analysis reveals that the VA strategy has lower average return and higher standard deviation compared to the BH strategy and has lower average return and lower standard deviation compared to the DCA strategy. These findings are in stark contrast to the claims made by advocates of VA strategy that the strategy improves investment performance.
\end{abstract}

Keywords: Value Averaging; Dollar-Cost Averaging; Buy-and-Hold; Fund; Investment Performance

JEL Classification: G10, G11, G18

* We thank KG Zeroin for providing fund data for this study. Professor Choe's research was supported by Institute of Management Research of Business School, Seoul National University..

** Corresponding Author. Address: College of Business and Economics, Sangmyung University, 20 Honggimun 2-gil, Jongno-gu, Seoul, Korea 03016; E-mail: ban9415@smu.ac.kr; Tel: +82-2-781-7586; Fax: +82-2-2287-0059.

Received: February 6, 2020; Revised: March 2, 2020; Accepted: March 10, 2020 


\title{
가치평준화 투자전략이 투자성과를 개선하는가?*
}

\author{
최 혁 (서울대학교 교수) \\ 반 주 일 (상명대학교 부교수)**
}

$<$ 요 약>

이 연구는 매기간 일정금액을 위험자산에 투자하는 적립식 투자전략(Dollar Cost Averaging)의 변형된 형태로서, 위험자산에 대한 투자목표 금액을 달성하기 위하여 매기간마다 투자금액을 조절하는 가치평준화 투자전략(Value Averaging)이 투자성과를 개선하는 효과가 있는지 분석하였다. 2001년부터 2019년 6월 까지 18.5년간의 펀드데이터를 이용하여 설정 및 환매에 제약이 없는 구조로서 투자자에게 판매가 되었던 주식형, 해외주식형, 커머더티형 펀드를 대상으로 $\mathrm{VA}$ 전략, $\mathrm{DCA}$ 전략, $\mathrm{BH}$ 전략(목돈을 일시에 투자하되 기대수익률이 DCA 전략과 같아지도록 위험자산 투자비율이 $50 \%$ 로 조정된 매입 후 보유(Buy and Hold) 투자전략)의 투자성과를 비교하였다. 실증분석 결과, VA 전략은 $\mathrm{BH}$ 전략에 비해 평균 수익률이 낮고, 표준편차는 높은 열등한 전략이며, DCA 전략에 비해 평균 수익률도 낮고, 표준편차도 낮은 전략인 것으로 나타났다. 이러한 연구 결과는 VA 전략이 투자성과를 개선하는 효과가 있다는 관련 서적 및 일부 선행연구들의 내용, 인터넷 카페 및 블로그 등에서 드러나고 있는 VA 전략 옹호자들의 주장과는 상반되는 것이다.

핵심 단어 : 가치평준화, 적립식, 매입 후 보유, 펀드, 투자성과

JEL 분류기호: G10, G11, G18

* 학술연구를 위해 펀드데이터를 제공해주신 (주)케이지제로인의 관계자 여러분께 감사드린다. 최혁의 연구는 서울대학교 경영대학 경영연구소 연구비 지원으로 수행되었다.

** 연락담당 저자. 주소: 서울특별시 종로구 홍지문 2길 20 상명대학교 경영경제대학 글로벌경영학과, 03016; E-mail: ban9415@smu.ac.kr; Tel: 02-781-7586; Fax: 02-2287-0059. 


\section{1. 서론}

가치 평준화 투자전략(Value Averaging, ${ }^{1)}$ 이하 VA 전략)이란 매기간 일정금액을 위험 자산에 투자하는 적립식 투자전략(Dollar Cost Averaging, 이하 DCA 전략) ${ }^{2)}$ 의 변형된 형태 로서, 위험자산에 대한 투자목표 금액을 달성하기 위하여 매기간마다 투자금액을 조절하는 전략을 일컫는다. 예를 들면, DCA 전략은 시장상황에 관계없이 매월 100만 원씩을 투자하여 상승장에서는 매입량이 줄어들고, 하락장에서는 매입량이 늘어나게 된다. 이렇게 함으로써 평균적인 매입단가를 인하시켜 투자성과를 개선시킬 수 있다는 것이 DCA 전략 옹호자들의 주장이다. VA 전략은 투자목표 금액을 100만 원(투자개시시점), 200만 원(1개월 후), 300만 원 (2개월 후), $\cdots$ 처럼 설정하고, 투자목표와 일치하도록 시장상황에 따라 매기간 투자금액을 조절하는 전략이다. 예컨대, 투자개시 시점에 100 만 원을 투자하였는데 한 달간 $10 \%$ 의 수익이 발생하였다면 투자금액을 90 만 원으로 줄여서 투자하고, 한 달간 $10 \%$ 의 손실이 발생하였다면 투자금액을 110 만 원으로 늘려서 투자하는 방식이다. 그러므로 VA 전략은 DCA 전략에 비해 상승장에서는 매입량을 더욱 줄이고 하락장에서는 매입량을 더욱 늘리게 된다. 이렇게 함으로써 매입단가 인하효과가 더욱 극대화될 수 있다는 것이 VA 전략 옹호자들의 핵심 논거 이다. VA 전략은 Edleson(1988)에 의해 학계에 처음으로 소개되었으며, Edleson(1991)과 Edleson $(2006)^{3)}$ 을 통해 투자성과를 개선하는 전략으로 대중들에게 알려져 있다.

그러나, VA 전략 및 DCA 전략이 추구하는 매입단가 인하효과는 행동재무학적으로만 의미를 가질 뿐 경제적으로 아무런 의미가 없다. 매입단가 인하효과가 의미가 없는 이유로, Sharpe (1981)는 매입단가 인하효과는 시장의 변동성에 의해 발생하지만 투자전략을 구사하여 역으로 변동성에 영향을 줄 수가 없기 때문이라고 보고 있다. Thorley(1994)는 이미 지나간 역사적 가격과 평균 매입단가 간의 차익거래가 불가능하기 때문이라고 설명하고 있다. 물론, 투자자들이 DCA나 VA 전략을 이용해 평균 매입단가를 낮추는 것은 손실이 발생하더라도 마치 손실을 덜 본 것처럼 인식하는 심리적 효과는 얻을 수는 있다(Statman, 1995).

이론상 매입단가 인하효과가 경제적 의미를 갖지 못함에도 불구하고 이 효과를 믿는 투자자 들이 많이 존재하는 것도 현실이다. 우리나라의 경우, 2004년 최초로 소개된 적립식 펀드를 통해 DCA 전략이 큰 인기를 얻어 하나의 투자문화로 자리잡을 정도로 널리 퍼져 나갔다. $\mathrm{VA}$ 전략은 비교적 최근에 와서야 인터넷 카페, 블로그 등을 통해 점차 투자자들에게 전파 되고 있다. 사용되는 명칭 또한 다소 혼란스러운 면이 있는데,'가치 분할매수', '가치 분할 투자법, '가치 평균법', ‘점증평가적립', ‘변액적립식’ 등 다양하게 사용되고 있는 실정이다.

1) Dollar Value Averaging이라는 명칭으로도 알려져 있으나, Value Averaging이 일반적으로 사용되는 명칭이다.

2) ‘적립식 투자전략' 또는 ‘정액적립식 투자전략'이라는 명칭으로 사용되고 있지만, '매입 단가 평준화 투자전략’이 의미에 충실한 번역이라고 판단된다.

3) 우리나라에는 '내 돈을 지키는 안전한 투자법(안세민 옮김)'이라는 책으로 번역되어 소개되었다. 
Does Value Averaging Strategy Improve Investment Performance?

펀드명칭에 '분할매수’라는 단어를 포함시켜 펀드수준(fund level)에서 VA 전략을 응용하는 펀드들도 꾸준히 생겨나고 있다. 이러한 펀드들은 운용펀드(모펀드와 클래스펀드 제외) 기준으로 2005년에 2개에 불과하였으나, 2019년 6월 말까지 총 101개가 생겨나고, 71 개가 사라져 2019년 6월 말 현재, 총 30개가 존재하고 있다.

이 논문은 우리나라의 공모펀드 데이터를 이용하여 VA 전략이 투자성과를 개선하는지 여부를 실증적으로 분석한다. 이 논문이 검증하고자 하는 내용은 크게 두 가지로 요약된다. 첫째, VA 전략이 DCA 전략에 비해 평균-분산 기준에서 투자성과를 개선할 수 있는가? 둘째, $\mathrm{VA}$ 전략이 $\mathrm{BH}$ 전략(목돈을 일시에 투자하되 기대수익률이 $\mathrm{DCA}$ 전략과 같아지도록 위험자산 투자비율이 50\%로 조정된 매입 후 보유(Buy and Hold) 투자전략)에 비해 평균-분산 기준 에서 투자성과를 개선할 수 있는가?

이 연구의 의의는 다음과 같이 요약할 수 있다. 첫째, 우리나라 시장에서 DCA 전략의 투자성과에 대해서는 Koh(2006), Song(2009), Park and Lee(2010), Choe and Ban(2010) 등 여러 실증 연구가 있지만, DCA 전략에 비해 정교한 전략으로 대중에게 알려진 VA 전략이 투자성과를 개선하는지에 대해 실증 분석한 연구는 $\mathrm{Cho}(2012)^{4)}$ 를 제외하고는 없는 것으로 파악된다. 둘째, 기존 실증연구들이 주로 S\&P500, KOSPI와 같은 시장지수 자료만을 이용 함으로써 분석의 범위가 매우 제한되어 다양한 투자대상에 투자하는 실제 투자자의 성과를 알기가 어려운데, 이 연구는 한 나라의 방대한 펀드데이터를 이용하였다는 점이다. 미국 투자회사협회(Investment Company Institute: ICI)의 2019년 발표자료에 따르면 우리나라는 2018년 9월 말 기준으로, 조세피난처 국가인 룩셈부르크를 제외하고는, 세계에서 가장 많은 펀드 수를 기록하는 국가로서 실증분석에 필요한 충분한 크기의 표본이 존재한다. 비록 우리나라 펀드산업의 업력이 짧아 선진국에 비해 데이터의 시계열이 짧긴 하지만 다양한 펀드 표본이 횡단면적으로 존재하는 까닭에 일반화된 결론을 이끌어내는 데 좋은 조건이라고 볼 수 있다.

현재까지 VA 전략이 투자성과를 개선하는가에 대한 실증연구는 몇 가지의 시장지수만을 대상으로 매우 제한적인 범위에서 진행된 것으로 보인다. Thorley(1994) 및 Leggio and Lien(2001)은 S\&P500 지수에, Leggio and Lien(2003)은 4가지 지수(S\&P500, 소형주, 장기회사채, 장기국채)에 1 년간 투자하는 경우의 성과를 분석하고 있으며, 공통적인 분석 대상인 S\&P500 지수에 한정할 경우 유사한 결과를 도출하고 있다. VA 전략의 평균 수익률과 표준편차가 모두 DCA 전략보다 낮게 나타나서 평균-분산 기준에서 VA 전략이 투자성과를 유의하게 개선한다는 증거는 발견되지 않았다. KOSPI 지수를 이용한 Cho(2012)의 연구 에서도 투자기간이 1 년인 경우에는 S\&P500 지수를 사용한 외국문헌과 유사한 결과가 도출 되었다. 다만, 투자기간이 5년, 10 년, 20년으로 길어지면 1 년인 경우와는 달리 VA 전략이

4) Cho(2012)는 1987년부터 2010년까지의 KOSPI 지수 데이터를 사용하였다. 본 연구는 2001년부터 2019년 6월까지의 우리나라 공모펀드 데이터를 사용하여 데이터의 양과 표본기간에 상당한 차이가 있다. 
한국증권학회지 제49권 3호 (2020)

DCA 전략보다 우수한 성과를 도출한다는 결과를 보여주고 있는데, 이러한 결과에 문제점은 없는지 제 4 장의 강건성 검증 부분에서 토의하고자 한다.

이 연구의 주요 결과는 다음과 같다. 2001년부터 2019년 6월까지 설정 및 환매에 제약이 없는 구조로서 ${ }^{5)}$ 투자자에게 판매가 되었던 주식형, 해외주식형, 커머더티(Commodity)형 펀드를 대상으로 $\mathrm{VA}$ 전략, $\mathrm{DCA}$ 전략, $\mathrm{BH}$ 전략의 투자성과를 비교하였다. 첫째, 매시점마다 모든 펀드에 분산 투자하는 투자자의 투자성과를 의미하는 역사적 성과분석 결과 VA 전략은 $\mathrm{BH}$ 전략에 비해 평균 수익률이 낮고, 표준편차는 높은 열등한 전략이며, DCA 전략에 비해 평균 수익률도 낮고, 표준편차도 낮은 전략인 것으로 나타났다. 또한, 샤프지수는 VA 전략이 3 가지 전략 중 가장 낮게 도출되었다. 둘째, 역사적 성과분석 결과로 얻어진 211 개의 시계열 관측치에서 무작위로 18 개씩 추출하는 작업을 10,000 회 반복하는 부트스트랩 시뮬레이션을 수행한 결과 VA 전략이 다른 투자전략에 비해 투자성과를 개선한다는 통계적인 증거는 발견되지 않았다. 셋째, 많은 펀드 중에서 몇 개의 펀드만을 선택적으로 투자하는 투자자의 입장에서 성과를 비교하기 위해 개별 펀드 수준에서의 윌콕슨 부호순위검정법을 사용한 결과, $\mathrm{VA}$ 전략은 $\mathrm{BH}$ 전략에 비해서 수익률이 낮고, 위험은 큰 전략이며, $\mathrm{DCA}$ 전략에 비해서는 상대적으로 수익률이 낮고, 위험이 낮은 전략인 것으로 나타났다. 종합해 볼 때 이러한 연구 결과들은 VA 전략이 투자성과를 개선하는 효과가 있다는 VA 전략 옹호자들의 믿음과 모두 상반되는 것이다.

이 연구의 구성은 다음과 같다. 제 2장에서는 데이터 및 연구방법론을 설명하고, 제 3장 에서는 수치예시, 역사적 성과분석, 부트스트랩 시뮬레이션 결과를 제시하였다. 부호순위 검정 결과를 제시하였다. 제 4장에서는 강건성 검증을 위해 개별 펀드 수준에서의 부호순위 검정 결과를 제시하고, 투자목표금액이 조정과 투자기간 증가의 영향은 어떠한지 논의하였다. 제 5 장에서는 이 연구의 주요결과를 요약하고 시사점을 제시하였다.

\section{2. 데이터 및 연구방법론}

\section{1 데이터}

\subsection{1 데이터의 구조}

이 연구는 우리나라의 대표적 펀드평가회사인 (주케이지제로인에서 제공한 펀드기본정보 및 펀드일별정보를 이용하여 수행되었다. 데이터는 2001년 1월 2019년 6월에 존재하였던 모든 펀드를 대상으로 하고 있으며, 총 펀드수는 54,789 개에 달한다. 펀드기본정보는 펀드코드, 펀드명칭, 운용사, 설정일, 해지일, 펀드유형분류, 벤치마크, 모-자 펀드구분, 프라이머리-

5) 펀드설정 후 추가적인 납입이 제한되어 있어 일정기간 동안만 자금을 모집하는 펀드를 단위형펀드, 언제든지 추가적으로 투자가 가능한 펀드를 추가형펀드라 한다. 한편, 펀드가 해지될 때까지 자금인출이 제한되는 펀드를 폐쇄형펀드, 언제든지 환매가 가능한 펀드를 개방형펀드라 한다. 이 연구에서는 개방형, 추가형 속성을 모두 만족하는 펀드만을 표본으로 하여 분석하였다. 
Does Value Averaging Strategy Improve Investment Performance?

클래스(Primary-Class) 펀드구분, 펀드보수, 펀드수수료, 추가형-단위형 펀드구분, 개방형폐쇄형 펀드구분 정보를 담고 있으며, 펀드일별정보는 펀드코드, 기준일, 순자산, 펀드수익률, 벤치마크수익률 정보를 포함한다. 또한 펀드일별정보는 공시일 기준으로 제공되었기 때문에 실제 운용일 기준과 1 영업일의 시차가 발생하므로 이 연구에서는 정확한 분석을 위하여 공시일을 운용일로 보정하는 작업 후에 사용하였다. 무위험자산 수익률로는 우리나라의 $\mathrm{CD}$ (91일물) 금리를 사용하였으며 한국은행 경제통계시스템(ECOS)으로부터 추출하였다.

\subsection{2 표본구성 및 데이터 이상치 처리}

VA 전략이 위험자산에 투자하는 시점을 타이밍하는 전략이므로 투자성과를 분석하기 위해서는 위험자산에 투자하는 펀드유형 ${ }^{6)}$ 을 표본으로 선정하는 것이 적절할 것으로 판단 된다. 무위험자산에 가까운 채권형, $\mathrm{MMF}$ 형 펀드 및 벤치마크가 채권시장지수를 기반으로 하는 혼합형, 절대수익추구형, 특별자산형, 기타형 펀드는 분석대상에서 제외하였다. 또한 $\mathrm{VA}$ 전략이 일정기간마다 추가적인 납입, 또는 환매가 이루어지는 전략이므로 설정일 이후 추가적인 납입 및 해지일까지 중도인출이 불가능한 경우가 많은 부동산형 펀드도 분석대상 에서 제외하였다. 최종적으로 3가지 유형(국내주식형, 해외주식형, 커머더티형)의 펀드만을 분석대상으로 하였다.

국내주식형, 해외주식형, 커머더티형 펀드 중에서, 알 수 없는 원인으로 인해 연속된 펀드일별 정보 수집에 실패하고 있는 기준가단절 펀드, 투자자에게 판매가 되지 않는 모펀드, 프라이머리 펀드, 추가적인 납입이 불가능한 단위형펀드, 중도인출이 불가능한 폐쇄형펀드, 펀드수명이 1 년 이하인 펀드는 표본에서 제외하였고, 1 차적으로 11,413 개의 펀드표본이 얻어졌다.

Choe and Ban(2010)에 설명된 바와 같이 일별수익률 데이터에 이상치가 존재하여 그대로 방치할 경우 이 연구의 분석결과가 왜곡될 수 있다. 일별수익률 데이터 이상치를 통제하기 위해서 윈저화(Winsorization) 기법을 적용하였다. 윈저화 기법의 구체적인 적용방법은 다음과 같다. 앞서 얻어진 11,413 개의 펀드표본에 대해서 날짜를 특정일로 고정하고 수익률이 상위 $1 \%$, 하위 $1 \%$ 분위수를 벗어나는 관측치에 대해서는 상위 $1 \%$ 분위수 값과 하위 $1 \%$ 분위수 값을 할당하여 이상치를 보정하였다.

펀드 설정 또는 해지가 발생하는 시점에서는 수익률 관측치가 일부 영업일에 대해서만 존재하므로 모든 영업일에 대해서 관측치가 존재하는 다른 펀드들과 비교가 불가능하다. 따라서 각 펀드마다 설정월(첫 달) 및 해지월(마지막 달)의 데이터는 사용하지 않았다. 펀드의 최초 설정 후 펀드 인큐베이션 ${ }^{7)}$ 으로 인한 수익률 왜곡, 펀드가 해지되기 직전 순자산 규모가

6) http://www.funddoctor.co.kr/board/aboard/fund_lecture_method.jsp에서는 (주)케이지제로인에서 사용하는 펀드유형 분류체계에 대한 설명을 제시하고 있다.

7) Fama and French(2010)는 펀드 인큐베이션에 대해 다음과 같이 설명하고 있다. “운용사가 보통 새롭게 설정되는 펀드들이 필요로 하는 초기 종자돈을 제공하고 수익률 기록을 쌓아 나가도록 한 후, 성과가 좋은 펀드만을 대중들에게 판매하는 성향이 있기 때문에 인큐베이션 편의(incubation bias)가 발생하게 된다." 펀드 인큐베이션에 대해 더 자세한 내용은 $\operatorname{Evans}(2010)$ 를 참조할 것. 
한국증권학회지 제49권 3호 (2020)

매우 작아지게 되어 순자산에 비해 규모가 큰 자금유출입이 이루어질 경우 수익률이 큰 폭으로 변동할 가능성 등을 통제하고자, 펀드가 설정된 후 1 년 및 펀드가 해지되기 전 6 개월 동안은 해당 데이터를 사용하지 않았다. 마지막으로, VA 전략을 구사하기 위해서는 위험 자산 목표에 맞추어 추가적인 투자 및 환매가 빈번하게 발생하게 되므로 선취수수료나 후취 수수료를 부과하는 펀드들은 해당 전략을 구사하기에 적합하지 않다고 판단되어 분석대상 에서 제외하였다. 최종적으로 6,455 개의 펀드가 분석대상 표본으로 선정되었다.

\section{2 연구방법론}

\subsection{1 수익률 계산}

\subsubsection{1 보유기간수익률과 내부수익률}

다기간에 걸쳐 투자전략의 수익률을 측정할 때, 보유기간수익률(Holding Period Return, 이하 HPR)을 사용할 것인지 아니면 내부수익률(Internal Rate of Return, 이하 IRR)을 사용할 것인지 여부는 중요한 문제이다. 일반 투자자 입장에서는 투자기간 전체 동안 필요한 자금을 투자개시시점에 모두 보유하고 있지 않다고 가정하여 매월 유입되는 현금을 통해 분할매수 투자전략(VA 전략, DCA 전략 등)을 구사하고 IRR을 측정하는 것이 현실적인 방법이라고 생각할 수도 있다. 그러나, 이러한 방법론은 자금을 일시에 투자하는 투자전략과 현금흐름 양상이 전혀 달라서 투자전략 간 비교가 어렵다. DCA 전략의 경우에는 매 기간의 투자금액이 고정되기 때문에 사전적으로 고정된 투자금액 외에 별도의 추가적인 자금이 투자기간 중 필요하지 않다. 이에 비해 $\mathrm{VA}$ 전략은 하락장이 지속되는 경우 사전적으로 정해 놓은 초기 자산을 모두 소진하고 추가적인 자금이 필요할 수도 있다. $\mathrm{BH}$ 전략은 투자개시시점에 한꺼번에 투자하므로 다른 투자전략에 비해 큰 규모의 초기자산을 가정할 수밖에 없다.

그러므로, 다양한 투자전략들의 투자성과를 공정하게 비교하기 위해서는 투자자가 투자 개시시점부터 투자기간 전체에서 필요한 자금을 모두 보유하여 초기자산 외에 추가적인 자금조달은 없는 것으로 가정하는 것이 합리적이다. 초기자산 중 위험자산에 투자되지 않은 여유자금은 무위험자산에 투자되고 있는 것으로 가정한다. 이 가정하에서 Thorley(1994), Leggio and Lien(2003), French(2009), Choe and Ban(2010)은 HPR을 측정하는 방법을 이용하고 있다. ${ }^{8)}$

IRR은 또 다른 문제점을 내포하고 있다. Hayley(2013)는 VA 전략의 성과를 IRR과 같은 금액가중수익률로 평가하게 되면 체계적인 상향 편의(bias)가 발생한다는 것을 수식으로

8) Chen and Estes(2007)은 투자개시 시점에 투자기간 전체에서 필요한 자금을 모두 보유하고 있다는 가정을 사용하지 않았다. 또한, 성과측정 방법으로 IRR도 채택하지 않고 있다. 401(k)퇴직연금에 매월 $\$ 1000$ 를 불입하는 투자자를 가정한 후 DCA 전략과 VA 전략에서 30년 후에 Terminal Wealth를 서로 비교하는 독특한 방법을 택하고 있는데, DCA 전략의 경우 불입금이 $401(\mathrm{k})$ 주식계좌 및 채권 계좌에 각각 30 대 70 으로 배분되며, VA 전략의 경우 매달 $0.5 \%$ 이상의 위험자산 투자 목표금액의 성장률을 가정하는 등 자의적인 요소가 많아서 다른 연구들과의 비교가능성은 낮다고 판단된다. 
Does Value Averaging Strategy Improve Investment Performance?

보이고 있다. Hayley(2014)는 IRR 사용시 편의가 발생하는 현상을 "Quit-While-Ahead Effect”라고 명명하면서, 동전던지기 게임에서 이겼을 때는 게임을 그만두고 졌을 때는 게임을 계속 진행하면 사후적인 승률을 높일 수 있는 것과 같다고 설명한다. 수익이 많이 발생하였을 때는 투자금액을 더욱 줄이고, 손실이 많이 발생하였을 때는 투자금액을 더욱 늘리는 VA 전략의 IRR이 부풀려지는 이유에 대한 적절한 비유라고 판단된다. 따라서, IRR을 측정하여 VA 전략이 DCA 전략보다 투자성과를 개선한다고 분석한 Marshall(2000, 2006)의 연구 결과는 IRR의 편의에 기인한 것으로 보인다.

\subsubsection{2 전략별 수익률 계산}

VA 전략의 투자성과를 분석하려면 비교대상이 될 투자전략이 필요하다. 이 연구에서는 2 가지(투자자들에게 인기가 많은 DCA 전략, DCA 전략의 성과분석을 위해 벤치마크로 활용 되는 $\mathrm{BH}$ 전략)를 비교대상으로 설정하였다. 각 투자전략은 다양한 방법으로 구체화될 수 있으나 여기서는 Thorley(1994)의 방법론을 사용하였다. Thorley(1994)는 1년 동안 각 투자전략을 실행하는 것으로 가정하고, DCA 전략 및 VA 전략을 벤치마크 전략인 $\mathrm{BH}$ 전략과 비교하기 쉽도록 $\mathrm{N}$ 기간 동안 매기 $1 /(\mathrm{N}+1)$ 의 비율로 투자하는 것으로 계산하여 투자원금의 평균 위험자산 노출도를 $50 \%$ 수준으로 맞춘다. ${ }^{9)}$ 예를 들어, 초기자산이 13 백만 원인 투자자를 가정하자. DCA 전략은 투자개시시점에 1 백만 원을 위험자산에 투자하고 이후에도 매달 1 백만 원씩 정액으로 위험자산에 대한 투자금액을 늘려나가는 전략이다. VA 전략은 위험 자산에 대한 투자목표금액을 투자개시시점부터 종료시점까지 각각 1 백만, 2 백만, 3 백만, $\cdots, 13$ 백만으로 설정하고 ${ }^{10)}$ 매달 시장상황에 따라 투자금액을 조절하여 투자한다. $\mathrm{BH}$ 전 략은 투자개시시점에 초기자산을 위험자산과 무위험자산에 50:50으로 배분하여 리밸런싱 없이 종료시점까지 보유하는 전략이다.

먼저, VA 전략의 수익률을 계산하는 방법은 다음과 같다. 총수익률(gross return)을 사용하는 경우 위험자산의 누적수익률 $\left(\mathrm{CUMRET}_{\text {risky,t }}\right)$, 무위험자산의 누적수익률 $\left(\mathrm{CUMRET}_{\text {free,t}}\right)$ 은 각각 식 (1), (2)와 같이 나타낼 수 있다. 투자개시 시점 $(\mathrm{t}=0)$ 에서의 총자산은 1 원, 누적수익률은 1 로 정의한다.

$$
\begin{aligned}
& \text { CUMRET }_{\text {risky }, \mathrm{t}}=\mathrm{CUMRET}_{\text {risky }, \mathrm{t}-1} \times \mathrm{RET}_{\text {risky }, \mathrm{t}} \\
& \mathrm{CUMRET}_{\text {free }, \mathrm{t}}=\mathrm{CUMRET}_{\text {free }, \mathrm{t}-1} \times \mathrm{RET}_{\text {free, } \mathrm{t}}
\end{aligned}
$$

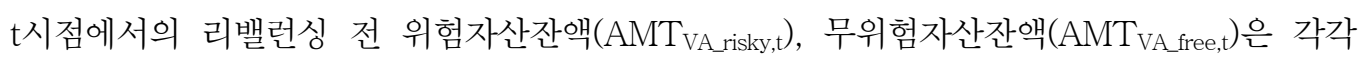
$\mathrm{t}-1$ 시점에서의 리밸런싱 후 위험자산잔액(FinalAMT $\mathrm{VArisky,t}_{\mathrm{t}}$, 무위험자산잔액(FinalAMT $\mathrm{VAfree,t}_{\mathrm{f}}$ )에

9) $\{1 / 12 \times(1 / 13+2 / 13+3 / 13 \cdots \cdots \cdot .+12 / 13)\}=50 \%$ 이므로 12 개월 동안 투자하는 경우 초기자산을 $1 / 13$ 씩 분할하여 투자해야 한다.

10) Edleson(2006)은, 이와 같이 투자목표 금액을 단순하게 선형으로 증가시켜가는 방법을 '선형가치 경로(linear value path)’라고 명명하고 있다. 
t시점의 위험자산수익률 $\left(\mathrm{RET}_{\text {risky,t }}\right)$, 무위험자산수익률 $\left(\mathrm{RET}_{\text {free, }}\right)$ 곱하여 산출되므로 이를 수식으로 표현하면 식 (3), (4)와 같다.

$$
\begin{aligned}
& \mathrm{AMT}_{\mathrm{VA}_{-} \text {risky,t }}=\text { FinalAMT }_{\mathrm{VA}_{-} \text {risky, },-1} \times \mathrm{RET}_{\text {risky, } \mathrm{t}} \\
& \mathrm{AMT}_{\mathrm{VA} \text { _free }, \mathrm{t}}=\text { FinalAMT }_{\mathrm{VA}_{-} \text {free, } \mathrm{t}-1} \times \mathrm{RET}_{\text {free, } \mathrm{t}}
\end{aligned}
$$

$\mathrm{VA}$ 전략의 $\mathrm{t}$ 시점 수익률 $\left(\mathrm{RET}_{\mathrm{VA}, \mathrm{t}}\right)$ 은 $\mathrm{t}-1$ 시점에 비하여 총자산이 얼마나 증가하였는지로 측정하며 식 (5)와 같이 표현된다.

$$
\mathrm{RET}_{\mathrm{VA}, \mathrm{t}}=\frac{\mathrm{AMT}_{\mathrm{VA} \_ \text {risky }, \mathrm{t}}+\mathrm{AMT}_{\mathrm{VA} \_ \text {free }, \mathrm{t}}}{\mathrm{AMT}_{\mathrm{VA}_{\text {risky,t-1 }}}+\mathrm{AMT}_{\mathrm{VA}_{\text {free, } t-1}}}
$$

$\mathrm{VA}$ 전략의 $\mathrm{t}$ 시점 누적수익률(CUMRET $\mathrm{VA}, \mathrm{t})$ 은 $\mathrm{t}-1$ 시점 누적수익률에 $\mathrm{t}$ 시점 수익률을 곱 하여 산출되며 식 (6)으로 표현된다.

$$
\mathrm{CUMRET}_{\mathrm{VA}, \mathrm{t}}=\mathrm{CUMRET}_{\mathrm{VA}, \mathrm{t}-1} \times \mathrm{RET}_{\mathrm{VA}, \mathrm{t}}
$$

$\mathrm{VA}$ 전략의 위험자산 투자 목표금액(TGT $\mathrm{TAArisky,t}_{\mathrm{t}}$ )은 투자개시 시점 $(\mathrm{t}=0)$ 에서 $1 / 13$ 원으로 투자종료 시점 $(\mathrm{t}=12)$ 까지 매월 $1 / 13$ 씩 증가하되, 무위험자산의 수익성이 최소한의 투자목표로 반영되도록 하는 경우(VA 전략을 통해 적어도 무위험자산 수익률 이상을 목표로 할 것이라는 가정 $)^{11)}$ 에 식 $(7)$ 과 같이 표현된다.

$$
\mathrm{TGT}_{\mathrm{VA} \_ \text {risky }, \mathrm{t}}=\frac{\mathrm{t}+1}{13} \times \mathrm{CUMRET}_{\text {free, } \mathrm{t}}
$$

VA 전략의 위험자산 리밸런싱 목표금액(RebalTGT $\mathrm{VA}_{\mathrm{V}, \mathrm{t}}$ )은 위험자산 투자 목표금액에서 t시점에서 보유하고 있는 위험자산 잔액을 차감하여 (8)과 같이 산출된다. 여기서 산출된 값이 음(-)일 경우 위험자산에 대한 추가적인 투자가 필요한 것이 아니라, 기존에 투자된 금액 중 일부를 회수해야 함을 의미한다.

$$
\text { RebalTGT }_{\mathrm{VA}, \mathrm{t}}=\mathrm{TGT}_{\mathrm{VA} \_ \text {risky,t }}-\mathrm{AMT}_{\mathrm{VA} \_ \text {risky,t }}
$$

실제 리밸런싱은 $\mathrm{t}$ 시점에서 보유한 무위험자산 잔액 한도 내에서 이루어져야 하므로, 리밸런싱 목표금액과 무위험자산 잔액의 크기를 비교하여 식 (9)와 같이 실제 리밸런싱 금액(RebalAMT $\mathrm{VA}_{\mathrm{t}, \mathrm{t}}$ )이 도출된다.

11) 투자목표 금액을 증가시켜가는 속도에 대한 가정이 달라지면 연구결과에 어떠한 영향을 미치는지 제 4 장 제 2절에서 논의하였다. 
Does Value Averaging Strategy Improve Investment Performance?

$$
\begin{aligned}
\text { RebalAMT }_{\mathrm{VA}, \mathrm{t}} & =\text { RebalTGT }_{\mathrm{VA}, \mathrm{t}}(\text { if RebalTGT } \\
& =\mathrm{AMT}_{\mathrm{VA}, \mathrm{t}}=<\mathrm{AMT}_{\mathrm{VA} \text { _free, }}(\text { if Rebalt } \mathrm{t} \text { ) } \\
& \left.=\mathrm{ATT}_{\mathrm{VA}, \mathrm{t}}>\mathrm{AMT}_{\mathrm{VA} \_ \text {free }, \mathrm{t}}\right)
\end{aligned}
$$

리밸런싱 후의 위험자산잔액(FinalAMTVA_risky,t $)$ 및 무위험자산잔액(FinalAMT VA_free,t $_{\text {t }}$ 은 각각 리밸런싱 전의 잔액에서 리밸런싱 금액을 가감하여 식 (10), (11)과 같이 산출된다.

$$
\begin{aligned}
& \text { FinalAMT }_{\mathrm{VA}_{-} \text {risky }, \mathrm{t}}=\mathrm{AMT}_{\mathrm{VA} \_ \text {risky,t }}+\mathrm{RebalAMT}_{\mathrm{VA}, \mathrm{t}} \\
& \text { FinalAMT }_{\mathrm{VA}_{-} \text {free,t }}=\mathrm{AMT}_{\mathrm{VA} \_ \text {free }, \mathrm{t}}-\mathrm{RebalAMT}_{\mathrm{VA}, \mathrm{t}}
\end{aligned}
$$

여기서,

$\mathrm{RET}_{\text {risky,t }}$ : 위험자산의 t월 수익률

$\mathrm{CUMRET}_{\text {risky,t }}$ : 위험자산의 $\mathrm{t}$ 월 누적수익률

$\mathrm{RET}_{\text {free,t }}$ : 무위험자산의 t월 수익률

CUMRET $_{\text {free,t }}$ : 무위험자산의 $\mathrm{t}$ 월 누적수익률

$\mathrm{AMT}_{\mathrm{VA}_{-} \text {risky,t }}: \mathrm{VA}$ 전략에서 $\mathrm{t}$ 월 말 시점에 위험자산에 투자된 금액(리밸런싱 전)

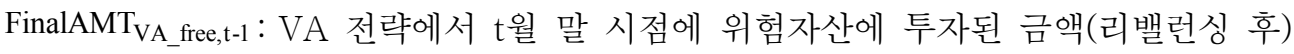

$\mathrm{AMT}_{\mathrm{VA} \text { free,t }}: \mathrm{VA}$ 전략에서 $\mathrm{t}$ 월 말 시점에 무위험자산에 투자된 금액(리밸런싱 전)

FinalAMT $_{\mathrm{VA}_{-} \text {free,t-1 }}$ : VA 전략에서 t월 말 시점에 무위험자산에 투자된 금액(리밸런싱 후)

$\mathrm{RET}_{\mathrm{VA}, \mathrm{t}}: \mathrm{VA}$ 전략의 $\mathrm{t}$ 월 수익률

$\mathrm{CUMRET}_{\mathrm{VA}, \mathrm{t}}$ : VA 전략의 $\mathrm{t}$ 월 누적수익률

$\mathrm{TGT}_{\mathrm{VA} \text { _risky,t }}$ : VA 전략의 $\mathrm{t}$ 시점에서의 위험자산 목표금액

RebalTGT $_{\mathrm{VA}, \mathrm{t}}$ : VA 전략의 $\mathrm{t}$ 시점에서의 리밸런싱 목표금액

RebalAMT $_{\mathrm{VA}, \mathrm{t}}$ : VA 전략의 t시점에서의 실제 리밸런싱 금액

$\mathrm{DCA}$ 전략 수익률을 계산하는 방법이 $\mathrm{VA}$ 전략에 비교하여 차이가 나는 점은 리밸런싱 금액이 시장상황에 따라 변화하지 않고 일정하다는 것이다. 투자개시 시점 $(\mathrm{t}=0)$ 에 전체자산 1 원을 13 등분하여 매달 위험자산에 $1 / 13$ 원씩 투자가 된다. 단, 투자개시 시점 $1 / 13$ 원은 리밸런싱이 이루어지는 시점에서 무위험자산의 누적수익률만큼 증가되어 있기 때문에 이러한 효과를 반영하여 식 (12)와 같이 위험자산에 투자하는 것으로 계산하였다. 여타의 계산은 위에서 설명하는 VA 전략과 동일하므로 생략하기로 한다.

$$
\text { RebalAMT }_{\text {DCA }, \mathrm{t}}=\frac{1}{13} \times \mathrm{CUMRET}_{\text {free }, \mathrm{t}}
$$

여기서,

RebalAMT $_{\mathrm{DCA}, \mathrm{t}}$ : DCA 전략의 $\mathrm{t}$ 시점에서의 실제 리밸런싱 금액 
한국증권학회지 제49권 3호 (2020)

마지막으로 $\mathrm{BH}$ 전략의 수익률을 계산하는 방법은 중간에 리밸런싱을 필요로 하지 않기 때문에 가장 간단하다. 투자개시 시점에 전체자산 1 원 중 $1 / 2$ 원을 각각 위험자산과 무위험 자산에 투자하고 보유하면 되므로 수익률은 식 (13)과 같이 $\mathrm{BH}$ 전략의 누적수익률이 계산 된다.

$$
\mathrm{CUMRET}_{\mathrm{BH}, \mathrm{t}}=\frac{1}{2} \times \mathrm{CUMRET}_{\text {risky }, \mathrm{t}}+\frac{1}{2} \times \mathrm{CUMRET}_{\text {free }, \mathrm{t}}
$$

여기서,

$\mathrm{CUMRET}_{\mathrm{BH}, \mathrm{t}}$ : $\mathrm{BH}$ 전략의 $\mathrm{t}$ 월 누적수익률

최종적으로, 각 투자전략을 12 개월 동안 실행 후 순수익률로 산출한 성과는 각각 $\mathrm{CUMRET}_{\mathrm{VA}, 12-1}, \mathrm{CUMRET}_{\mathrm{DCA}, 12-1}, \mathrm{CUMRET}_{\mathrm{BH}, 12-1}$ 이다.

\subsection{2 분석방법}

\subsubsection{1 수치예시}

실제 데이터를 활용한 분석에 앞서, Thorley(1994), Choe and Ban(2010)에서 사용된 수치예시(Numerical Illustration) 방법론을 사용하여 VA 전략의 성과가 시장상황에 따라 어떠한 특성을 나타내는지 살펴본다. 실무자들과 일반인들은 VA 전략이 DCA 전략에 비하여 위험자산의 가격이 낮을 때 더욱 많은 양을 매입하고, 가격이 높을 때는 더욱 적은 양을 매입함으로써 수익률이 개선된다고 생각하기 쉽다. 이러한 생각은 금액가중수익률이 가져오는 착시현상에 불과하다는 것을 보이는 것이 수치예시의 주 목적이라고 할 수 있다. 몇 가지의 주가 움직임을 가정하고 시장국면(상승장, 횡보장, 하락장)별로 VA 전략, DCA 전략, $\mathrm{BH}$ 전략의 성과를 측정하되, 시간가중수익률(time weighted return)과 금액가중수익률(dollar weighted return)을 각각 산출하여 비교하기로 한다.

\subsubsection{2 역사적 성과분석}

12 개월 이상의 수익률 데이터가 존재하고 최종적으로 선택된 6,455 개의 펀드 표본에 대해서 2000년 12월 말부터 2019년 6월 말까지 각 투자전략 마다 매월 말에 투자를 개시 하여 12 개월 동안 전략을 실행하는 것으로 가정하여 3 가지 투자전략(VA, DCA, BH)에 대하여 펀드별로 수익률을 측정한다. 표본기간 전체에 걸쳐 생존하였던 펀드가 있다고 가정하면, 211개의 수익률이 존재한다(첫 번째 수익률은 2000년 12월 말부터 2001년 12월 말까지 측정, 마지막 수익률은 2018년 6월 말부터 2019년 6월 말까지 측정). 펀드별 수익률을 횡단면 평균(순자산가치 가중평균 또는 동일가중평균)을 구한 후 다시 211개의 시계열에 대해서 평균, 중간값, 표준편차, 최대값, 최소값을 계산한다. 역사적 성과분석의 경제적 의미는 매 시점마다 모든 펀드에 동일가중 또는 순자산가치가중 방식으로 분산 투자하는 투자자의 투자성과에 해당한다는 점이다. 
Does Value Averaging Strategy Improve Investment Performance?

\subsubsection{3 부트스트랩 시뮬레이션(Bootstrap Simulation)}

역사적 성과분석을 통해 총 211 개의 관측치를 얻게 되지만 수익률이 1 개월마다 측정됨 으로써 인접한 수익률과 11 개월의 기간이 중복(overlapping)되어 관측치들 간에 독립성이 보장되지 않는다. 따라서 전략간 평균의 차이 및 분산의 비율을 검정하는 일반적인 통계 분석을 실행하기 어렵다. 수익률을 12 개월마다 측정하는 경우 시계열에 독립성은 얻어지지만, 관측치가 18 개에 불과해 의미 있는 결론을 유도하기가 힘들어진다. 이러한 문제점을 극복하기 위하여 부트스트랩 시뮬레이션 기법을 활용하기로 한다. 부트스트랩 시뮬레이션은 표본을 모집단처럼 취급하여 표본에서 새로운 표본을 다시 추출한 후에, 새로운 표본을 통해 통계량을 얻어내는 기법이다. 본 연구에서는 먼저 역사적 성과분석결과 얻어진 211 개의 수익률 관측치 에서 무작위로 18 개씩을 추출하되, 이러한 추출작업을 10,000 회 반복하였다. 이를 통해 각 투자전략의 통계량(수익률, 위험 등)을 계산하고, 투자전략 간의 성과에 유의한 차이가 있는지를 부트스트랩 분위수법(bootstrap percentile method)을 이용해 p-value를 계산하여 검정하였다.

\section{3. 투자전략간 성과비교}

\section{1 수치예시(Numerical Illustraion)}

투자개시 시점(time 0)에서 초기자산(Initial Wealth) 50,000원을 보유한 투자자가 4기간 동안 각 투자전략 $(\mathrm{VA}, \mathrm{DCA}, \mathrm{BH})$ 을 실행한다. 위험자산의 가격은 100 원에서 출발하여, 1 기간 동안 $30 \%$ 상승 또는 $23.077 \%$ 하락을 동일확률로 반복한다고 가정하였다. 상승시 수익률과 하락시 수익률을 이와 같이 차이 나게 설정한 이유는 투자개시 시점과 투자종료 시점간 가격 변화가 전혀 없는 횡보장이 표현되도록 하기 위함이다. ${ }^{12)}$ 또한, 상승시 수익률이 하락시 수익률 보다 크게 설정된 이유는 위험자산의 양(+)의 위험프리미엄(risk premium)을 표현 하기 위함이다. 무위험자산 수익률은 편의상 $0 \%$ 로 가정하였다.

위험자산의 가격경로는 총 16 가지가 존재하며 1 개의 가격경로가 관찰될 확률은 $\frac{1}{16}$ 이다. 가격경로를 3 가지로 범주화하여 상승장(상상상상, 상상상하, 상상하상, 상하상상, 하상상상), 횡보장(상상하하, 상하상하, 상하하상, 하하상상, 사상상하, 하상하상), 하락장(상하하하, 하상하하, 하하상하, 하하하상, 하하하하)으로 구분하였다.

VA 전략의 위험자산 평가금액 목표치(Target)는 시점별로 각각 10,000 원, 20,000원, 30,000 원, 40,000 원, 50,000 원이며, DCA 전략과 동등한 비교를 위해 하락장이 지속되어 위험자산 평가금액이 목표치에 미달하더라도 추가적인 자금조달은 불가능한 것으로 가정 하였다.

12) $(1+0.30) \times(1-0.23077) \approx 1$. 
한국증권학회지 제49권 3호 (2020)

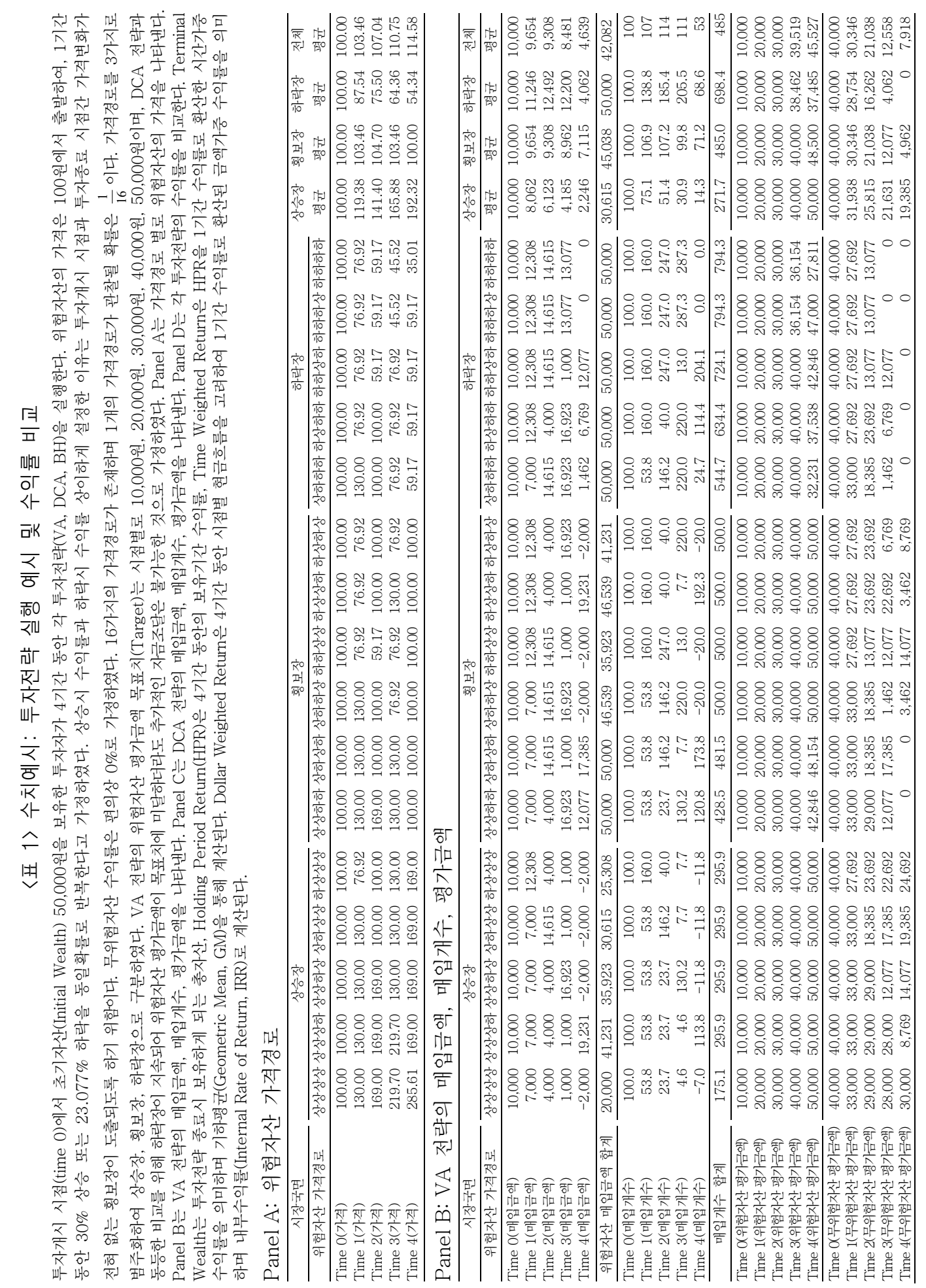


Does Value Averaging Strategy Improve Investment Performance?

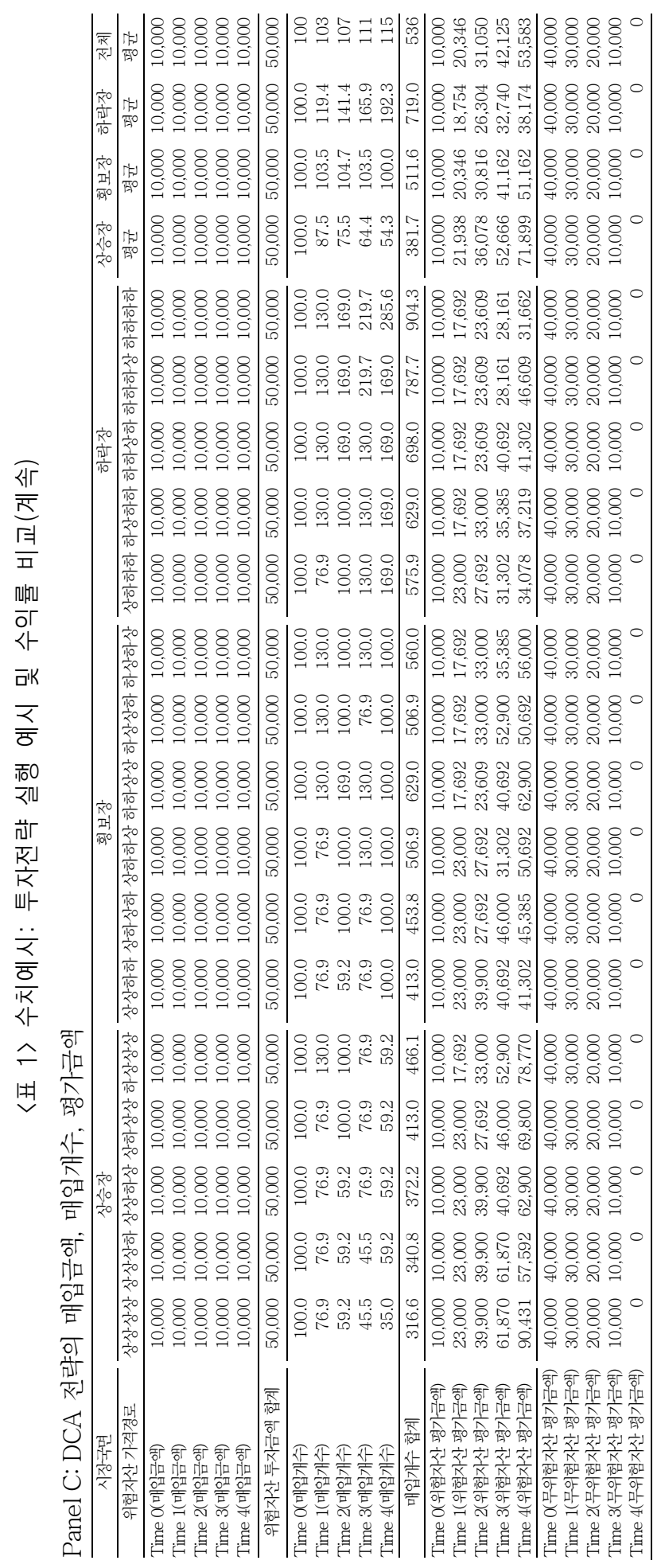


한국증권학회지 제49권 3호 (2020)

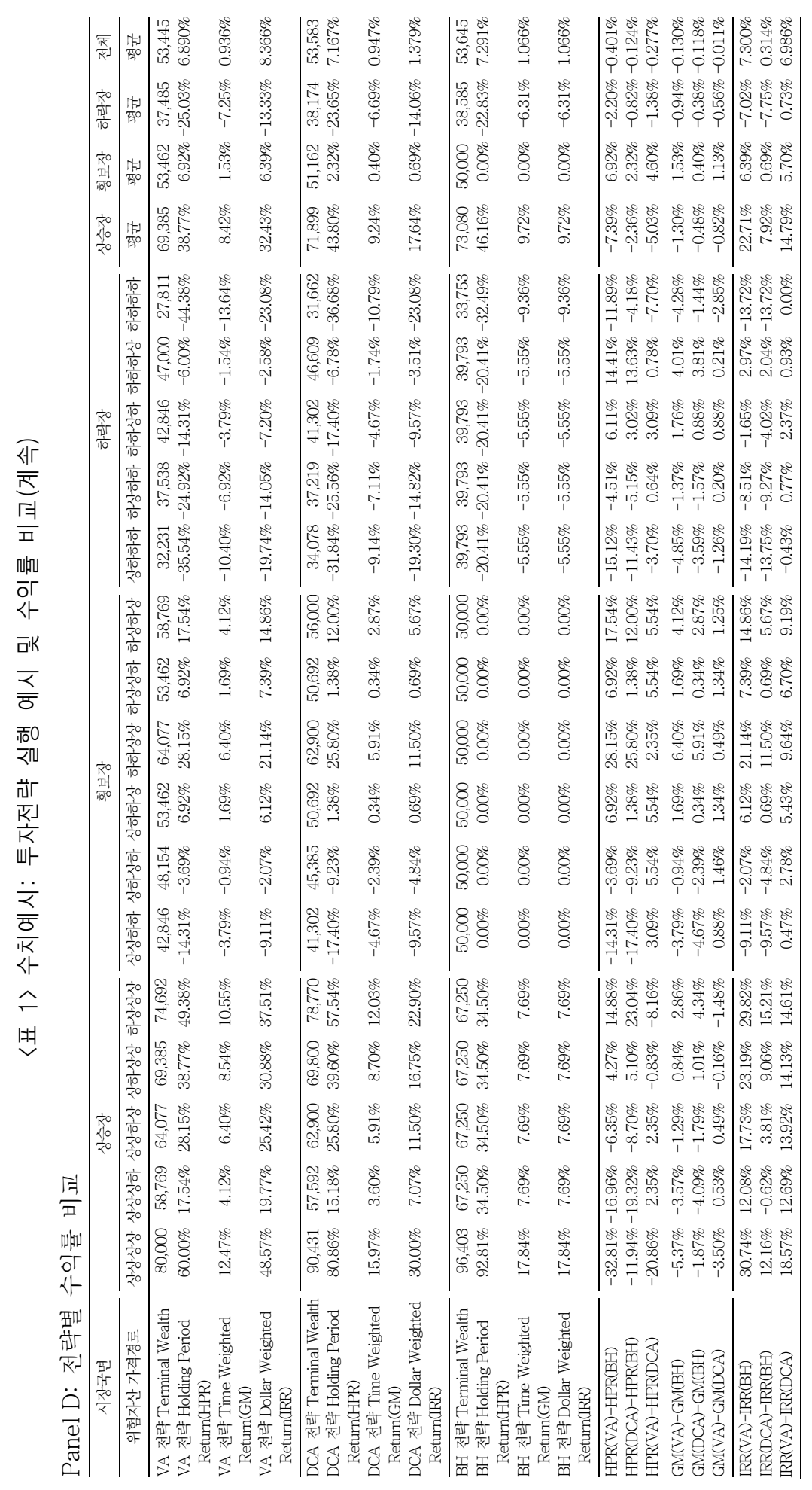


Does Value Averaging Strategy Improve Investment Performance?

<표 1>의 Panel A는 가격경로 별로 위험자산의 가격을 나타낸다. 4기간 동안 상승장, 횡보장, 하락장에서 수익률 평균은 각각 $92.32 \%, 0 \%,-45.66 \%$ 수준으로 각 시장의 성격이 잘 드러나고 있고, 시장국면 전체 평균은 $14.58 \%$ 로서 양(+)의 리스크 프리미엄도 표현되고 있어 수치예시를 제시하기에 적절한 조건임을 알 수 있다.

Panel B는 VA 전략의 매입금액, 매입개수, 평가금액을 나타낸다. 매입금액이 음(-)인 경우는 위험자산 목표치를 초과하게 되어 추가적인 투자가 아닌 환매가 발생하는 경우를 표현하고 있다. 매입금액이 영(0)인 경우는 무위험자산이 모두 소진되어 위험자산에 추가 적인 투자를 할 수 없는 경우를 표현하고 있다. 위험자산 평가금액이 시점별로 10,000 원, 20,000원, 30,000원, 40,000원, 50,000원에 미달하는 경우는 목표하는 리밸런싱을 달성할 수 있을 만큼의 무위험자산을 충분히 확보하지 못한 상황을 표현하고 있다. 4 기간 동안 상승장, 횡보장, 하락장에서의 위험자산 매입개수는 각각 271.7개, 485개, 698.4개이며 매 입금액은 각각 30,615원, 45,038원, 50,000원으로서, 상승장에서는 매입개수와 매입금액을 더욱 작게 하고 하락장에서는 매입개수와 매입금액을 더욱 크게 하는 VA 전략의 특성이 잘 드러나고 있다.

4 기간 경과 후 상승장, 횡보장, 하락장에서의 위험자산 평가금액은 각각 50,000원, 48,500원, 37,485 원으로 상승장을 제외하고는 목표를 달성하지 못하였음을 보여준다. 시장국면 전체 평균은 45,527원으로 역시 목표를 달성하지 못하고 있다. 자금조달에 제약이 존재하는 실제 투자자들 입장에서 VA 전략의 위험자산 투자금액 목표치를 매 시점마다 달성하는 것이 현실적으로 어려울 수 있음을 말해준다.

Panel C는 DCA 전략의 매입금액, 매입개수, 평가금액을 나타낸다. VA 전략과의 근본적인 차이는 시장상황에 관계없이 매입금액이 일정하다는 점이다. 4 기간 동안 상승장, 횡보장, 하락장에서 위험자산 매입개수는 각각 381.7 개, 511.6개, 719 개로서 VA 전략과 비교하여 각 국면에서의 차이가 보다 작음을 볼 때, $\mathrm{VA}$ 전략이 $\mathrm{DCA}$ 보다 위험자산 매매시점에 대한 타이밍을 보다 적극적으로 구사하는 전략임을 알 수 있다. 따라서, 이러한 타이밍이 유효 하다면 VA 전략의 성과가 좋을 것이지만, 타이밍 전략이 유효하지 못하다면 VA 전략의 성과가 DCA 전략에 비해 나은 점이 없고 오히려 변동성만 키우게 될 것으로 판단된다.

Panel D는 각 투자전략의 수익률을 비교한다. Terminal Wealth는 투자전략 종료시 보유하게 되는 총자산, Holding Period Return(HPR)은 4기간 동안의 보유기간 수익률, Time Weighted Return은 HPR을 1기간 수익률로 환산한 시간가중 수익률을 의미하며 기하평균(Geometric Mean, GM)을 통해 계산된다. Dollar Weighted Return은 4기간 동안 시점별 현금흐름을 고려하여 1 기간 수익률로 환산된 금액가중수익률을 의미하며 IRR로 계산된다.

먼저, 시장국면 평균 $\mathrm{GM}$ 을 살펴보면 $\mathrm{VA}$ 전략 $(0.936 \%)<\mathrm{DCA}$ 전략 $(0.947 \%)<\mathrm{BH}$ 전략 (1.066\%) 순으로 나타나서 VA 전략이 수익률을 개선하는 효과는 관찰되지 않고 있다. 반대로 $\mathrm{IRR}$ 을 살펴보면 $\mathrm{VA}$ 전략(8.366\%) >> DCA 전략(1.379\%)> $\mathrm{BH}$ 전략(1.066\%)으로 나타 나는데, $\mathrm{VA}$ 전략의 IRR이 $\mathrm{DCA}, \mathrm{BH}$ 전략에 비하여 과도하게 부풀려져 있으며, $\mathrm{DCA}$ 전략의 
한국증권학회지 제49권 3호 (2020)

IRR 또한 BH 전략에 비해 다소 부풀려져 있음을 알 수 있다. 이러한 결과는 IRR의 편의에

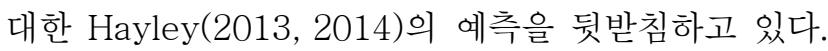

IRR의 편의에 따른 왜곡은 상승장에서 가장 두드러지게 관찰되고 있으며, VA 전략이 $\mathrm{DCA}$ 전략 및 $\mathrm{BH}$ 전략 보다 실제적으로 우수한 성과를 나타내는 국면은 횡보장에 국한 되고 있다. 시장국면이 횡보장일 때 이를 미리 적절히 예측하고 VA 전략을 구사하는 경우가 아니라면 VA 전략을 통해 수익률을 개선하기 어렵다는 것을 말해주고 있다. 위험자산의 속성상 위험프리미엄이 존재하므로, 장기적인 관점에서 상승장이 형성된다는 사실을 감안 한다면 $\mathrm{VA}$ 전략은 $\mathrm{DCA}$ 전략 및 $\mathrm{BH}$ 전략에 비해 열등한 전략이라고 판단된다.

\section{2 역사적 성과 분석결과}

<표 2〉는 VA 전략, $\mathrm{DCA}$ 전략, $\mathrm{BH}$ 전략의 투자성과 및 전략 간의 우열을 나타낸다. Panel A 및 Panel C는 수익률 관측치가 12 개월 이상인 6,455개의 펀드 표본에 대해서 2000년 12월 말부터 2019년 6월 말까지 각 투자전략 마다 매월 말에 투자를 개시하여 12 개월 동안 전략을 실행 후 각 펀드 별로 $\mathrm{VA}$ 전략, $\mathrm{DCA}$ 전략, $\mathrm{BH}$ 전략 수익률을 측정한 후 펀드 별 수익률을 모든 펀드에 대하여 횡단면 평균(순자산가치 가중평균 또는 동일가중 평균)을 구한 후 다시 211개의 시계열에 대해서 평균, 중간값, 표준편차, 최대값, 최소값을 구한 결과이다. Panel B 및 Panel D는 211개 관측치 중 각 전략이 다른 투자전략의 수익률을 앞선 관측치 수와 확률을 나타낸다.

Panel A에서 각 전략의 수익률 평균은 $\mathrm{VA}$ 전략 $(7.53 \%)<\mathrm{DCA}$ 전략 $(7.87 \%)<\mathrm{BH}$ 전략 (7.95\%) 순서이며, 표준편차는 $\mathrm{BH}$ 전략 $(11.30 \%)<\mathrm{VA}$ 전략 $(12.36 \%)<\mathrm{DCA}$ 전략(12.92\%) 순서이다. 따라서, $\mathrm{VA}$ 전략은 평균-분산 기준에서 $\mathrm{BH}$ 전략에 비해 열등한 전략이며, $\mathrm{VA}$ 전략은 DCA 전략보다 저위험-저수익 전략임을 알 수 있다. 샤프지수는 VA 전략(0.340) $<\mathrm{DCA}$ 전략 $(0.352)<\mathrm{BH}$ 전략(0.409) 순서로 VA 전략이 가장 열등한 전략임을 말해준다. $\mathrm{VA}$ 전략이 다른 비교전략에 비해 성과를 개선한다고 말하기는 어렵다. 이러한 결과들은 미국시장에서 S\&P500 지수를 투자대상으로 하여 각 투자전략의 투자성과를 비교한 Thorley(1994)의 실증분석 결과와 일치하고 있다. Panel B에서 VA 전략 수익률이 BH 전략 및 $\mathrm{DCA}$ 전략을 앞설 확률은 각각 $49.8 \%, 55.5 \%$ 로서 전략 간에 $\mathrm{VA}$ 전략 수익률이 다른 전략을 능가할 가능성 측면에는 뚜렷한 우열이 관찰되지는 않고 있다.

가중방식을 동일가중으로 바꾼 Panel C에서도 VA 전략이 다른 비교전략에 비해 성과를 개선한다는 증거는 발견하기 어렵다는 점에서 Panel A의 결과와 유사하다. 가중방식을 바껐을 경우 $\mathrm{VA}$ 전략, $\mathrm{DCA}$ 전략, $\mathrm{BH}$ 전략에서 수익률이 대략 $0.9 \%$ 1\% 가량 감소하였는데 이는 소규모 펀드들의 수익률이 대형 펀드들에 비해 더 작기 때문에 발생하는 현상이다. 이와 같은 우리나라 펀드의 음(-)의 규모효과(size effect)는 Ban and Choe(2013)에서 도출한 결과와 일치하며, 해외시장을 분석한 Beckers and Vaughan(2001), Chen et al.(2004), Indro et al.(1999), Chan et al.(2009)에서 도출된 양(+)의 규모효과와는 상반되는 연구결과이다. 
Does Value Averaging Strategy Improve Investment Performance?

〈표 2〉각 투자전략의 역사적 성과

수익률 관측치가 12 개월 이상인 6,455개의 펀드 표본에 대해서 2000년 12월 말부터 2019년 6월 말 까지 각 투자전략 마다 매월 말에 투자를 개시하여 12 개월 동안 전략을 실행하는 것으로 가정하고 각 펀드별로 $\mathrm{VA}$ 전략, $\mathrm{DCA}$ 전략, $\mathrm{BH}$ 전략 수익률을 측정한다. 이렇게 구해진 펀드별 수익률을 모든 펀드에 대하여 횡단면 평균(순자산가치 가중평균 또는 동일가중평균)을 구한 후 다시 211개의 시계 열에 대해서 평균, 중간값, 표준편차, 최대값, 최소값을 구한다. Panel A는 펀드의 규모효과를 반영 하기 위해 순자산가치 가중방식을 적용하였고, Panel B는 규모효과를 무시한 동일가중방식을 택하였다.

Panel A: 순자산가치 가중 역사적 성과

\begin{tabular}{|c|c|c|c|c|}
\hline & 펀드수 & VA전략 & DCA전략 & BH전략 \\
\hline 평균 & 1,771 & $7.53 \%$ & $7.87 \%$ & $7.95 \%$ \\
\hline 중간값 & 2,040 & $5.89 \%$ & $5.69 \%$ & $5.97 \%$ \\
\hline 표준편차 & 1,123 & $12.36 \%$ & $12.92 \%$ & $11.30 \%$ \\
\hline 최소값 & 378 & $-31.26 \%$ & $-28.68 \%$ & $-19.64 \%$ \\
\hline 최대값 & 4,370 & $43.62 \%$ & $49.76 \%$ & $37.49 \%$ \\
\hline 샤프지수 & & 0.340 & 0.352 & 0.409 \\
\hline \multicolumn{5}{|c|}{ Panel B: 순자산가치 가중 전략간 우열 } \\
\hline & 전체 & $\mathrm{VA}>\mathrm{BH}$ & $\mathrm{DCA}>\mathrm{BH}$ & $\mathrm{VA}>\mathrm{DCA}$ \\
\hline 관측수 & 211 & 105 & 104 & 117 \\
\hline 확률 & & $49.8 \%$ & $49.3 \%$ & $55.5 \%$ \\
\hline \multicolumn{5}{|c|}{ Panel C: 동일 가중 역사적 성과 } \\
\hline & 펀드수 & VA전략 & DCA전략 & BH전략 \\
\hline 평균 & 1,771 & $6.65 \%$ & $6.95 \%$ & $6.91 \%$ \\
\hline 중간값 & 2,040 & $5.54 \%$ & $5.19 \%$ & $5.70 \%$ \\
\hline 표준편차 & 1,123 & $11.57 \%$ & $11.94 \%$ & $10.35 \%$ \\
\hline 최소값 & 378 & $-31.25 \%$ & $-28.24 \%$ & $-19.07 \%$ \\
\hline 최대값 & 4,370 & $41.06 \%$ & $46.61 \%$ & $34.55 \%$ \\
\hline 샤프지수 & & 0.287 & 0.304 & 0.346 \\
\hline \multicolumn{5}{|c|}{ Panel D: 동일 가중 전략간 우열 } \\
\hline & 전체 & $\mathrm{VA}>\mathrm{BH}$ & $\mathrm{DCA}>\mathrm{BH}$ & $\mathrm{VA}>\mathrm{DCA}$ \\
\hline 관측수 & 211 & 108 & 109 & 113 \\
\hline 확률 & & $51.2 \%$ & $51.7 \%$ & $53.6 \%$ \\
\hline
\end{tabular}

\section{3 부트스트랩 시뮬레이션 분석결과}

<표 3>는 역사적 성과분석결과 얻어진 211개의 시계열 관측치에서 무작위로 18 개씩 추출하는 작업을 10,000회 반복하는 부트스트랩 시뮬레이션을 수행한 결과이다. 18 개씩 추출하는 이유는 표본기간이 18.5년이고, 12 개월 동안 투자전략을 실행했을 경우 최소한 18 개의 독립된 관측치가 확보되기 때문이다. ${ }^{13)}$ 시뮬레이션을 통해 각 투자전략의 통계량과 통계량의 표준오차를 계산하고 투자전략 간의 성과에 유의한 차이가 있는지를 검정하기

13) 211개 시계열 관측치에서 무작위로 211 개씩 추출하는 작업을 10,000 회 반복하는 경우 부트스트랩 시뮬레이션의 통계적 유의성은 높일 수 있으나, 211 개 관측치 간에는 독립성이 없기 때문에 추출된 표본 또한 독립성을 상실하게 된다. Choe and $\operatorname{Ban}(2010)$ 은 이러한 문제점을 반영하지 않고 있다. 


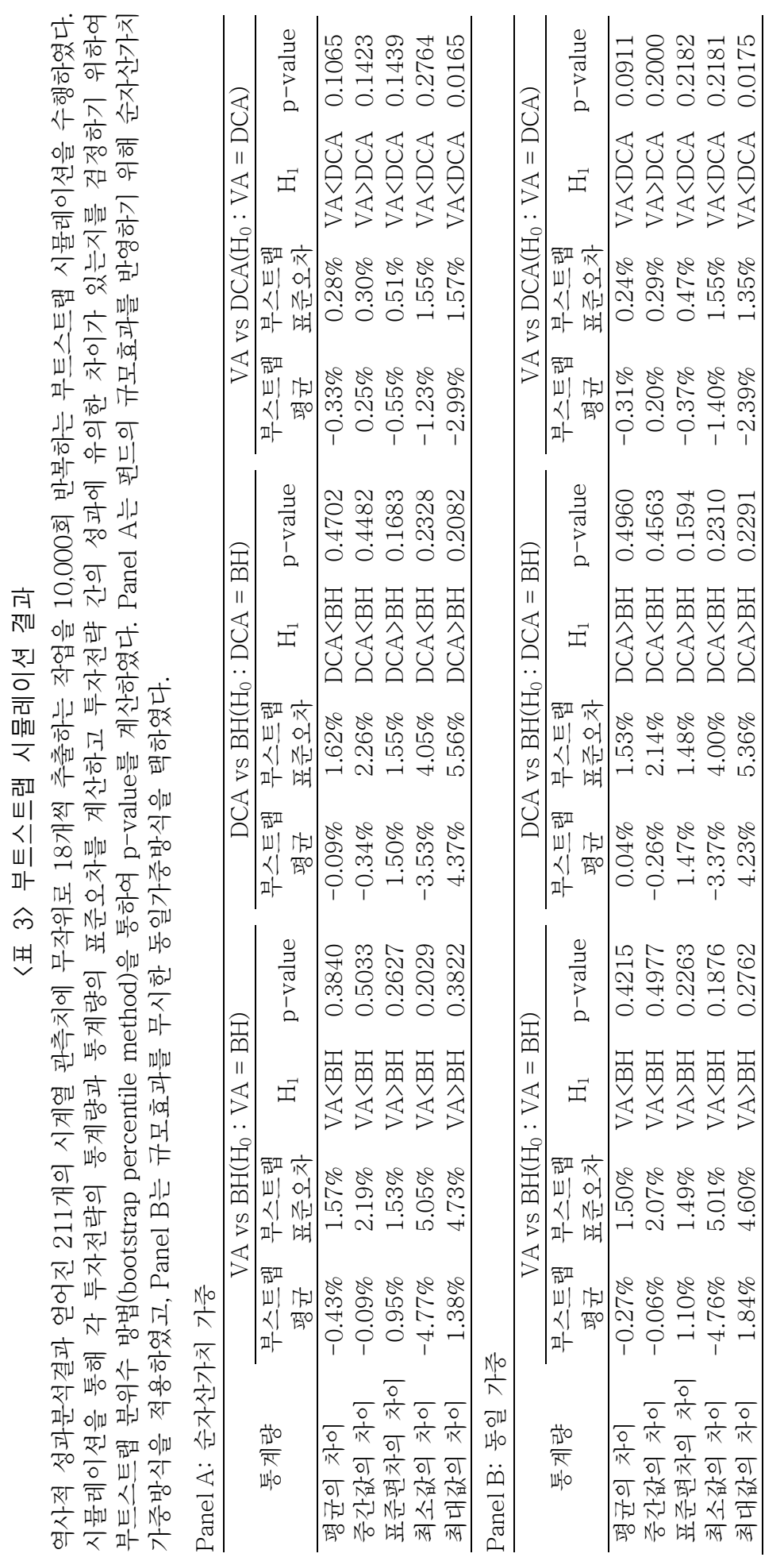


Does Value Averaging Strategy Improve Investment Performance? Evidence from the Korean Fund Market

위하여 부트스트랩 분위수법(bootstrap percentile method)을 통하여 $\mathrm{p}$-value를 계산하였다. Panel A에서 순자산가치 가중방식을 통해 VA 전략과 $\mathrm{BH}$ 전략을 비교할 경우 VA 전략의 수익률 평균은 $\mathrm{BH}$ 전략보다 $0.43 \%$ 낮고, 표준편차는 $0.95 \%$ 높게 나타나 $\mathrm{BH}$ 전략이 평균 -분산 기준에서 VA 전략을 지배하는데, 통계적으로 유의하지 않다. VA 전략과 DCA 전략을 비교할 경우, $\mathrm{VA}$ 전략의 수익률 평균은 $\mathrm{DCA}$ 보다 $0.33 \%$ 낮고, 표준편차 또한 $0.55 \%$ 낮게 나타나는데 역시 통계적인 유의성은 낮다. 표준편차가 낮아지는 효과는 최소값의 차이가 $-1.23 \%$, 최대값의 차이가 $-2.99 \%$ 임을 볼 때, 가장 큰 손실을 방어하기 보다는 가장 큰 이익 가능성을 감소시켜 생겨나는 현상이라는 점을 시사한다. 중간값의 차이가 $0.25 \%(\mathrm{VA}$ 전략의 수익률 중간값이 DCA 전략의 수익률 중간값보다 크게 나타남) 인데, 이는 <표 1>의 수치예시 결과에서 보았듯이 $\mathrm{VA}$ 전략이 시장국면 전체 평균에서 $\mathrm{DCA}$ 전략보다 나은 점이 없음에도, 횡보장에서만 $\mathrm{VA}$ 전략의 성과가 더 우수하게 나타난 점과 일치하는 결과라고 할 수 있다. 종합해볼 때 VA 전략이 다른 투자전략에 비해 투자성과를 개선한다는 증거는 발견되지 않았다. 가중방식을 동일가중으로 바꾼 Panel B에서 순자산가치 가중방식과 비교해 다른 점은 $\mathrm{VA}$ 전략의 수익률 평균이 $\mathrm{DCA}$ 전략의 수익률 평균보다 낮다는 결과가 유의 수준 $10 \%$ 에서 통계적으로 유의하다는 것이다. 다른 결과들은 모두 Panel $\mathrm{A}$ 의 결과와 유사하여 별도의 해석은 생략하기로 한다.

\section{4. 강건성 검증}

\section{1 개별펀드 수준에서의 부호순위 검정}

역사적 성과분석과 부트스트랩 시뮬레이션 방법은 여러 펀드들의 영향이 합산된 펀드 시장 전체에서 각 투자전략의 성과를 관찰하는 것이다. 많은 펀드 중에서 몇 개의 펀드를 선택하여 투자하는 투자자 입장에서는 개별 펀드 수준에서 어떤 투자전략이 보다 나은 성과를 도출하는지가 더욱 중요할 수 있다. 개별 펀드 수준에서 각 투자전략별 성과를 비교하기 위해서 비모수적 검정 방법인 윌콕슨 부호순위검정을 사용하였다. 역사적 성과분석과 부트스트랩 시뮬레이션 방법과 달리 각 투자전략에 대하여 개별 펀드 수익률의 표준편차를 계산하기 위해서 수익률 데이터가 13 개월 이상 존재하는 6,309개의 펀드를 표본으로 사용하되 특정 연도에 설정된 펀드가 결과를 좌우해버리는 것을 막기 위해 설정년도 별로 그룹화하였다. 부호순위 검정 절차는 다음과 같다. 먼저 $\mathrm{n}$ 개의 펀드들이 속해 있는 그룹 $\mathrm{i}$ 에서 펀드 1 을 추출한다. 만약 펀드 1 의 월별 수익률데이터가 24 개월 동안 연속으로 존재할 때 12 개월 수익률 시계열 데이터는 13 개(1M 12M, 2M 13M, 3M 14M, 4M 15M, 5M 16M, 6M 17M, 7M 18M, 8M 19M, 9M 20M, 10M 21M, 11M 22M, 12M 23M, 13M 24M)가 구해 진다. 13 개의 수익률 시계열 데이터를 이용하여 각 투자전략을 구사한다고 가정할 경우 $\mathrm{VA}$ 전략, $\mathrm{DCA}$ 전략, $\mathrm{BH}$ 전략의 수익률 평균, 중간값, 표준편차, 최소값, 최대값을 계산할 
수 있다. VA 전략과 $\mathrm{DCA}$ 전략의 수익률 평균값이 서로 다른지 $\mathrm{n}$ 개의 펀드를 이용하여 검정하고자 한다면 $\{$ 평균 $\mathrm{VA}$,펀드 $1-$ 평균 $\mathrm{DCA}$,펀드 $\},\{$ 평균 $\mathrm{VA}$,펀드 2 평균 $\mathrm{DCA}$,펀드 2$\}, \cdots,\left\{\right.$ 평균 $\mathrm{VA}$,펀드 $\mathrm{n}^{-}$ 평균 $\mathrm{DCA}$,펀드 $\mathrm{n}$ 과 같이 총 $\mathrm{n}$ 개의 부호순위 검정통계량을 구하고, 검정통계량의 순위를 계산한 후 순위를 합하여 윌콕슨 부호순위통계량을 산출하게 된다.

<표 4> 개별 펀드 수준에서의 부호순위 검정 결과이다. VA 전략과 $\mathrm{BH}$ 전략, $\mathrm{DCA}$ 전략과 $\mathrm{BH}$ 전략, $\mathrm{VA}$ 전략과 $\mathrm{DCA}$ 전략을 대응비교(paired comparison)하기 위해서 두 전략간 통계량의 차이를 계산하였다. 사용된 통계량은 수익률의 평균, 중간값, 표준편차, 최소값, 최대값이다. Panel A에서는 각 전략의 성과 차이를 통해 검정통계량(평균의 차이, 중간값의 차이, 표준편차의 차이, 최소값의 차이, 최대값의 차이)을 구축하고, 검정통계량의 평균값을 계산하여 나타내었다. Panel B는 부호순위 검정결과를 나타낸다. 설정연도에 따른 펀드 수를 살펴보면 연도에 따라 설정되는 펀드 수가 큰 차이를 보이고 있음을 알 수 있는데, 그룹화를 하지 않을 경우 특정 시장상황에서 설정된 펀드들의 영향력이 결과를 좌우해버릴 가능성이 있다는 증거이다.

먼저 $\mathrm{VA}$ 전략과 $\mathrm{BH}$ 전략을 비교해 보자. 평균차이(VA평균-BH평균)의 평균의 부호는 18 개 그룹 중 12 개가 음(-)으로 유의하게 관찰되고 있어, VA 전략은 평균 수익률 측면에서 $\mathrm{BH}$ 전략보다 불리함을 말해주고 있다. 중간값차이(VA중간값-BH중간값)의 평균의 부호는 16 개 그룹에서 양(+)으로 유의하게 관찰되고 있는데, 이는 앞서 살펴본 부트스트랩 시뮬레이션 결과와는 상반되고 있다. 중간값 측면에서 $\mathrm{VA}$ 전략이 $\mathrm{BH}$ 전략보다 유리하다는 것인데, 이 역시 수치예시에서 살펴보았듯이 VA 전략이 횡보장에서만 가장 나은 수익률을 가져온 점과 관련이 있다고 판단된다. 표준편차차이(VA표준편차-BH표준편차)의 평균의 부호는 18 개 그룹 전부에서 양(+)으로 관찰되고 있는데, $\mathrm{VA}$ 전략의 위험이 $\mathrm{BH}$ 전략보다 크다는 점을 말해준다. 최소값차이(VA최소값- $\mathrm{BH}$ 최소값)의 평균의 부호는 17 개 그룹에서 음(-)으로 관찰되고 있는데, $\mathrm{VA}$ 전략이 $\mathrm{BH}$ 전략보다 최대손실 가능성을 더욱 키우고 있음을 말해준다. 최대값차이(VA 최대값- $\mathrm{BH}$ 최대값)의 평균의 부호는 혼재되어 있어 최대이익의 가능성 측면 에서 어떤 전략이 좋은지는 판단하기 어렵다. 종합해보면, $\mathrm{VA}$ 전략은 $\mathrm{BH}$ 전략에 비해서 수익률이 낮고, 위험은 큰 전략임을 알 수 있다.

다음으로 $\mathrm{VA}$ 전략과 $\mathrm{DCA}$ 전략을 비교해 보자. 평균차이(VA평균-DCA평균)의 평균의 부호는 18 개 그룹 중 10 개가 음(-)으로 유의하고, 양(+)으로 유의한 그룹은 6 개인데, 대체로 $\mathrm{VA}$ 전략은 평균 수익률 측면에서 $\mathrm{DCA}$ 전략보다 불리함을 말해주고 있다. 중간값 차이 (VA 중간값-DCA 중간값)의 평균의 부호는 18 개 그룹에서 양(+)으로 유의하게 관찰되고 있는데, 이는 앞서 살펴본 부트스트랩 시뮬레이션 결과와 일치한다. 중간값 수익률 측면에서 $\mathrm{VA}$ 전략이 $\mathrm{DCA}$ 전략보다 유리하다는 것인데, 이 역시 수치예시에서 살펴보았듯이 VA 전략이 횡보장에서 $\mathrm{DCA}$ 전략 보다 높은 수익률을 달성한 점과 일치하는 결과라고 할 수 있다. 표준편차차이(VA표준편차-DCA표준편차)의 평균의 부호는 15 개 그룹에서 음(-)으로 관찰 
Does Value Averaging Strategy Improve Investment Performance? Evidence from the Korean Fund Market

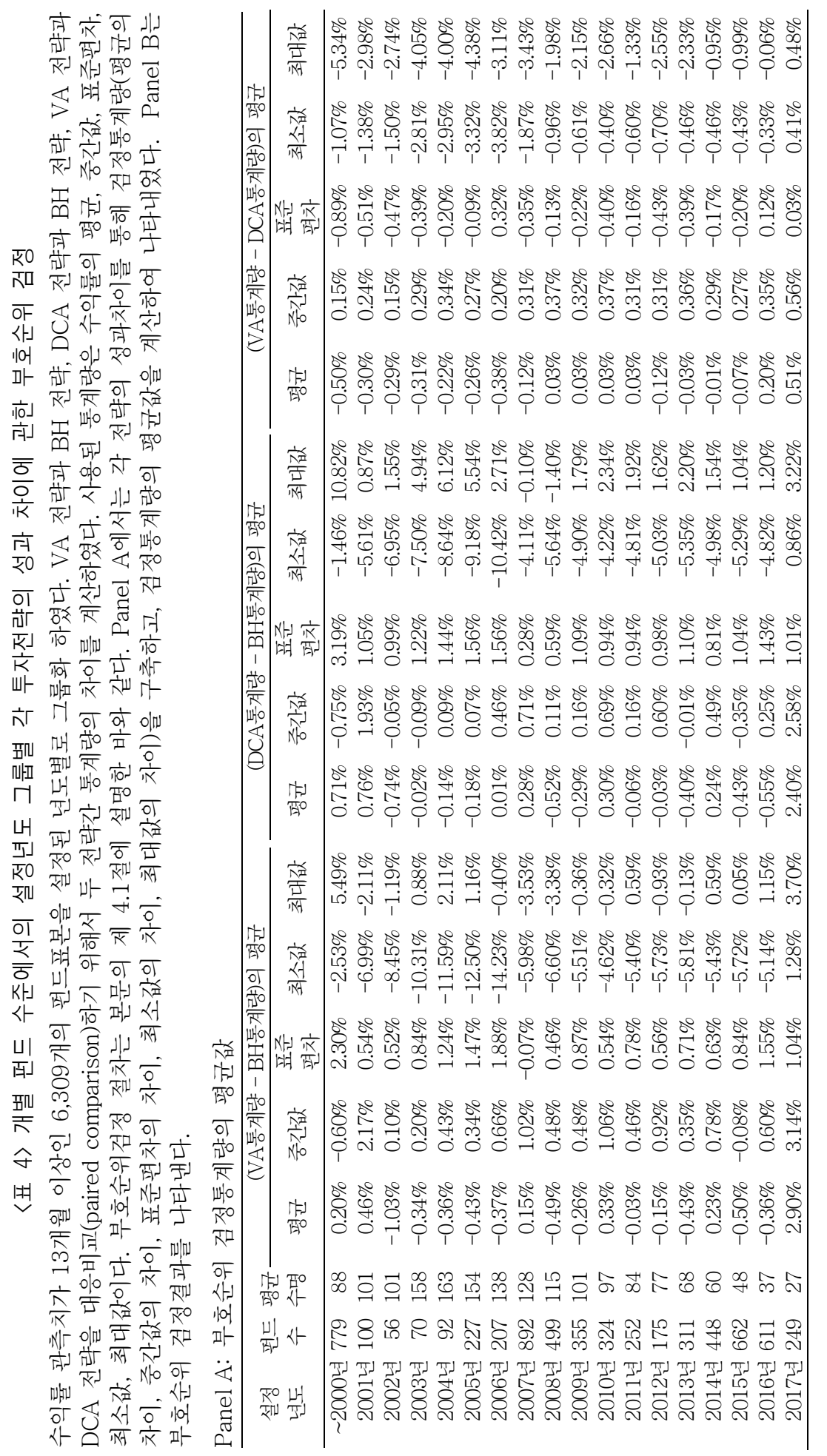




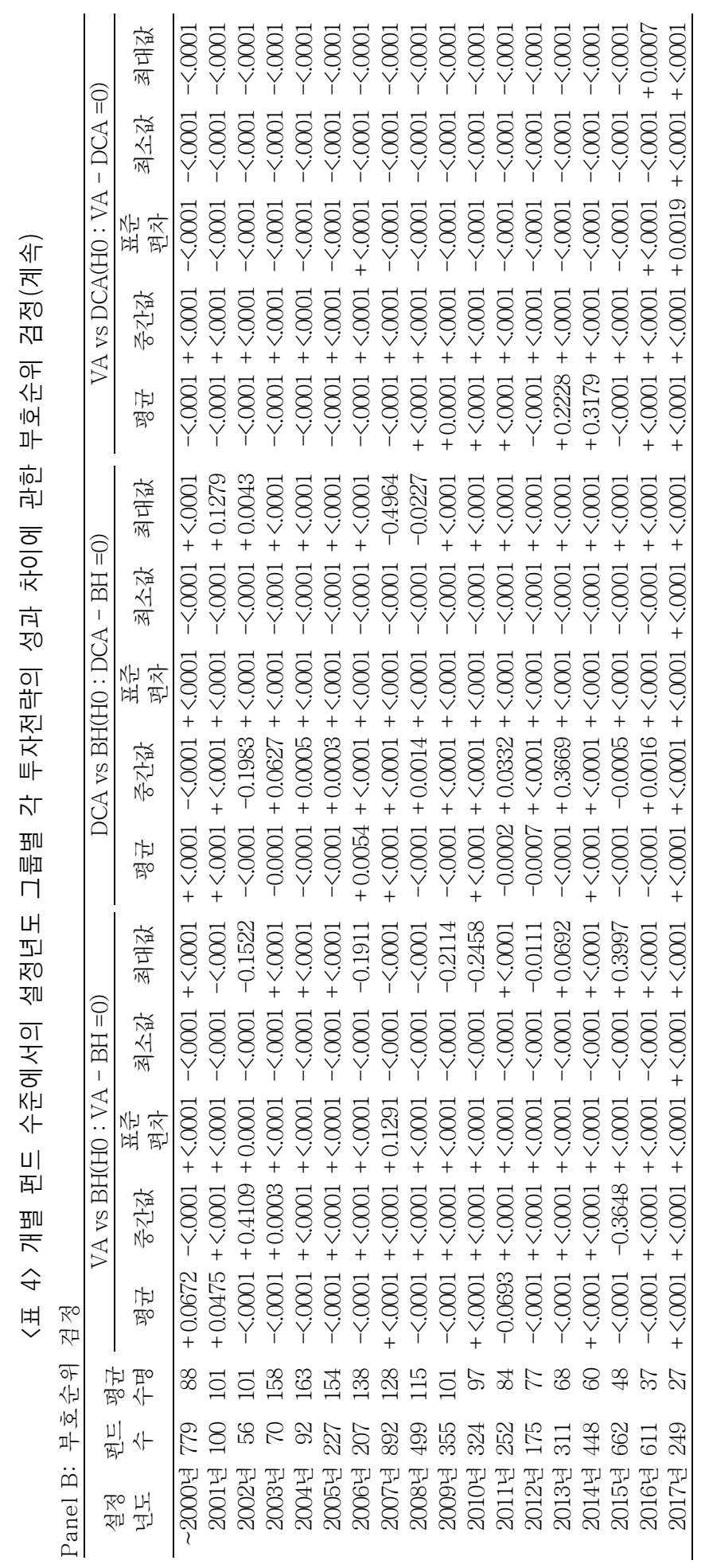


Does Value Averaging Strategy Improve Investment Performance? Evidence from the Korean Fund Market

되고 있는데, $\mathrm{VA}$ 전략의 위험이 $\mathrm{DCA}$ 전략보다 작다는 점을 말해준다. 최소값차이(VA 최소값-DCA 최소값)의 평균의 부호는 17 개 그룹에서 음(-)으로 관찰되고 있는데, VA 전략이 $\mathrm{DCA}$ 전략보다 최대손실 가능성이 크다는 점을 말해준다. 최대값차이(VA 최대값-DCA 최대값)의 평균의 부호는 16 개 그룹에서 음(-)으로 관찰되고 있는데, 최대이익 가능성 측 면에서 VA 전략이 불리함을 말해준다. 종합해보면, VA 전략은 DCA 전략에 비해서 상대 적으로 수익률이 낮고, 위험이 낮은 전략임을 알 수 있다. 이러한 결과는 역사적 성과분석, 부트스트랩 시뮬레이션 결과와 일치하고 있다.

\section{2 투자목표금액 조정}

Edleson(2006)은, 투자목표 금액을 복리효과를 반영하여 증가시켜 가는 방법을 '복리 가치경로(compounding value path)' 또는 '성장조정가치경로(growth-adjusted value path)' 라고 명명하고 있으며, 투자목표 금액을 단순하게 선형으로 증가시켜가는 '선형가치경로 (linear value path)'에 비해 보다 나은 방법으로 보고 있다. Thorley(1994)에서는 별도의 설명이 제시되지 않고 있는데, ‘linear value path'방법을 사용한 것으로 추측된다. 이 연구 에서는 'compounding value path'를 사용하되 투자목표금액(value)의 성장속도는 식 (7)에 표시된 바와 같이 무위험자산의 수익률로 가정하였다. 한편, Edleson(2006)은 뮤추얼펀드를 활용하여 VA 전략을 구사하는 방법에 대해 설명하면서 투자목표금액의 성장속도를 위험 자산의 기대수익률과 무위험자산의 수익률의 평균값으로 설정하는 방법을 예시로 제시하고 있다. VA 전략을 구사하게 되면 자산의 일부는 위험자산에 투자되고 나머지는 무위험자산에 투자되므로 이렇게 평균값을 사용하는 것이 합리적인 방법이라고 판단되지만, 사전적으로 위험자산의 기대수익률이 결정되어야 한다는 약점이 존재한다. 저자들은 강건성 검증차원 에서 이 방법을 사용하여 보았다. 이 연구에서 분석대상으로 삼은 펀드 표본들이, 표본기간 동안 월평균 $0.8767 \%$ 의 수익률을 보였다. 이 값을 위험자산의 기대수익률로 가정하고, 무위험자산 수익률과 평균하여 투자목표금액(value)의 성장속도로 사용한 실증분석 결과를 원래의 방법을 사용한 실증분석 결과와 비교할 때, $\mathrm{VA}$ 전략의 평균적인 수익률과 위험이 다소 증가했을 뿐, 주목 할만한 차이점은 발견되지 않았다.

\section{3 장기투자}

본 연구에서 $\mathrm{VA}, \mathrm{DCA}, \mathrm{BH}$ 전략의 성과는 각 전략을 1 년 동안 구사하는 것으로 가정하여 측정하였고, $\mathrm{VA}$ 전략이 투자성과를 개선한다는 사실을 발견하지 못하였다. 만약 투자기간을 3년, 5년, 10년, 20년 등으로 증가시켜 장기투자 성과를 측정한다면 VA 전략이 우수한 성과를 도출할 가능성은 없는지 토의해 볼 수 있겠다. 먼저, 이러한 장기투자 성과에 관한 연구는 상당히 긴 기간의 데이터를 필요로 한다. 저자들은 18.5년간(2001년 1월 2019년 6월)의 데이터를 이용하였음에도 자기상관(autocorrelation)이 없는 측정구간 비중복(non-overlapping)의 
한국증권학회지 제49권 3호 (2020)

1 년 수익률 시계열 데이터가 18 개에 불과함을 주지할 필요가 있다. 데이터의 개수는 투자 기간이 3 년, 5 년으로만 늘어나더라도, 6 개, 3 개로 급감하여 통계적 분석이 거의 불가능하게 된다. 우리나라보다 훨씬 장기인 미국 지수데이터를 활용한 선행연구들도 투자기간을 1 년으로 가정하여 분석하고 있고, ${ }^{14)}$ 장기투자의 성과는 1 년 성과를 오랫동안 측정한 평균치 등으로 유추하는 것으로 보인다.

저자들은 장기투자의 성과 또한 1 년 투자의 성과와 다르지 않을 것이라고 판단한다. 수치 예시 방법을 사용한 <표 1>에서 보았듯이 VA 전략은 상승장과 하락장에서 비교전략에 비해 불리하며 횡보장에서 우월한 성과를 내기 때문에, 장기적으로 가격이 상승하는 위험 자산의 속성을 고려할 때 VA 전략은 장기적으로 불리한 성과를 도출할 가능성이 크다.

이러한 관점에서, 24년간(1987년 2010년)의 데이터를 사용하여 투자기간이 10년, 20년이 되었을 때 VA 전략이 우월한 성과를 도출한다고 보고한 $\mathrm{Cho(2012)의} \mathrm{결과는} \mathrm{측정구간}$ 중복(overlapping) 수익률 문제를 간과하여 통계적 유의성을 확보하지 못하는 약점이 존재 한다. 또한 코스피 지수에서 발생하는 배당을 무시함으로써 장기적으로 상승하는 주가지수의 속성이 제대로 반영되지 못하여 연구데이터가 실제현실에 비해 횡보장의 성격을 갖게 됨으로써 VA 전략에 유리하게 투자성과가 측정되는 편의(bias)가 발생한 것으로 판단된다.

\section{5. 결론}

매기간 일정금액을 위험자산에 투자하는 DCA 전략을 변형하여 위험자산에 대한 투자목표 금액을 달성하기 위하여 매기간마다 투자금액을 조절하는 VA 전략은, 해외에서 1988년에는 학계에, 1991년에는 대중들에게 소개되면서 투자성과를 개선하는 전략으로 알려져 있다. 그러나, 학계에서는 VA 전략이 투자성과를 개선한다는 뚜렷한 증거는 보고되지 않고 있으며, 선행연구들이 주로 S\&P500과 같은 시장지수 자료만을 이용하여 분석함으로써 다양한 투자 대상에 투자하는 실제 투자자의 성과를 알기가 어려운 상황이다. 한편, 우리나라에서 VA 전략은 비교적 최근에 와서야 인터넷 카페, 블로그 등을 통해 점차 투자자들에게 알려지고 있고, VA 전략이 투자성과를 개선하는가에 대하여 이루어진 연구는 전무한 실정이다. 이러한 배경하에서, 이 연구는 2001년부터 2019년 6월까지 우리나라의 공모펀드 데이터 중 주식형, 해외주식형, 커머더티(Commodity)형 펀드를 이용하여 VA 전략이 DCA 전략 및 $\mathrm{BH}$ 전략에 비해 평균-분산 기준에서 투자성과를 개선할 수 있는지 분석하였다. 이 연구의 주요결과는 다음과 같다.

첫째, 매 시점마다 모든 펀드에 분산 투자하는 투자자의 투자성과를 의미하는 역사적 성과분석 결과 $\mathrm{VA}$ 전략은 $\mathrm{BH}$ 전략에 비해 평균 수익률이 낮고, 표준편차는 높은 열등한

14) Thorley(1994)는 66년간(1926 1991), Leggio and Lien(2003)은 74년간(1926 1999)의 장기 지수데이터를 이용함에도 불구하고 VA 전략의 투자성과를 측정함에 있어 투자기간을 1 년으로 설정하였다. 
Does Value Averaging Strategy Improve Investment Performance? Evidence from the Korean Fund Market

전략이며, DCA 전략에 비해 평균 수익률도 낮고, 표준편차도 낮은 전략인 것으로 나타났다. 또한, 샤프지수는 VA 전략이 3가지 전략 중 가장 낮게 도출되었다. 둘째, 역사적 성과분석 결과로 얻어진 211 개의 시계열 관측치에서 무작위로 18 개씩 추출하는 작업을 10,000 회 반복하는 부트스트랩 시뮬레이션을 수행한 결과 VA 전략이 다른 투자전략에 비해 투자성과를 개선한다는 증거는 발견되지 않았다. 셋째, 많은 펀드 중에서 몇 개의 펀드만을 선택적으로 투자하는 투자자의 입장에서 성과를 비교하기 위해 개별 펀드 수준에서의 윌콕슨 부호순위 검정법을 사용한 결과, $\mathrm{VA}$ 전략은 $\mathrm{BH}$ 전략에 비해서 수익률이 낮고, 표준편차는 큰 전략이며, $\mathrm{DCA}$ 전략에 비해서 상대적으로 수익률이 낮고, 표준편차가 낮은 전략인 것으로 나타났다.

참고로, $\mathrm{VA}$ 전략의 성과특성에 대한 직관을 얻기 위해 간단하게 시장국면(상승장, 횡보장, 하락장)을 가정한 수치예시법을 통해, VA 전략의 시간가중수익률(기하평균으로 측정)이 다른 전략에 비해 평균적으로 낮음에도 불구하고 금액가중수익률(IRR로 측정)은 가장 높게 부풀려짐을 확인하였다. VA 전략이 실제적으로 우수한 성과를 나타내는 국면은 횡보장에 국한되었다.

상기한 결과들을 종합해 볼 때, 이러한 연구 결과들은 평균-분산 기준에서 $\mathrm{VA}$ 전략은 $\mathrm{BH}$ 전략에 비해 열등한 전략이며, $\mathrm{DCA}$ 전략에 비해 저위험, 저수익 전략이라고 볼 수 있다. 따라서, VA 전략이 투자성과를 개선하는 효과가 있다는 믿음은 근거가 없다고 하겠다. IRR을 이용하여 VA 전략 및 DCA 전략과 같은 동적인 투자전략(Dynamic Strategies)의 성과를 분석하는 경우 수익률이 부풀려질 가능성이 있기 때문에 투자자들의 주의가 요구되며, 보유 기간수익률을 사용하는 방법이 권장된다. 또한, $\mathrm{VA}$ 전략이 평균적으로 열등한 성과를 보임에도 불구하고, 횡보장에서의 좋은 성과만을 예로 들어 VA 전략이 우수하다고 홍보하는 주장에도 현혹되지 말아야 할 것이다. 어느 누구도 시장상황을 사전적으로 예측하기 어렵고, 장기적으로 가격이 상승하는 위험자산의 속성을 감안한다면, $\mathrm{VA}$ 전략은 좋은 전략이라고 할 수 없기 때문이다. 


\section{References}

Ban, J., and H. Choe, 2013, Fund Size and Performance in a Market Crowded with Many Small Funds, Asia-Pacific Journal of Financial Studies, Vol. 42, pp. 340-372.

Beckers, S., and G. Vaughan, 2001, Small is beautiful, Journal of Portfolio Management, Vol. 27, pp. 9-17.

Chan, Howard W. H., Robert W. Faff, David R. Gallagher, and Adrian Looi, 2009, Fund size, transaction costs and performance: Size matters!, Australian Journal of Management, Vol. 34, pp. 73-96.

Chen, H., and J. Estes, 2007, Value averaging for 401(k) plans makes more 'cents' than dollar-cost averaging, Journal of Financial Planning, Vol. 20, pp. 56-59.

Chen, J., H. Hong, M. Huang, and J. D. Kubik, 2004, Does fund size erode mutual fund performance?, The role of liquidity and organization, American Economic Review, Vol. 94, pp. 1276-1302.

Cho, S., 2012, Searching for Optimal Investment Fund Allocation Strategy: Focusing on Value Averaging Strategy, Journal of Finance \& Knowledge Studies, Vol.10, pp. 5577.

Choe, H., and J. Ban, 2010, Does Dollar Cost Averaging Strategy Improve Investment Performance? Evidence from the Korean fund Market, Korean Journal of Financial Studies, Vol. 39, pp. 573-609.

Edleson, M. E., 1988, Value averaging: A new approach to accumulation, American Association of Individual Investors Journal, Vol. 10, pp. 11-14.

Edleson, M. E., Value averaging: The safe and easy investment strategy for higher investment returns, International Publishing Corporation, Chicago, 1991.

Edleson, M. E., Value averaging: The safe and easy strategy for higher investment returns, 2nd ed., John Wiley \& Sons, New Jersey, 2006.

Evans, R. B., 2010, Mutual fund incubation, Journal of Finance, Vol. 65, pp. 1581-1611.

Fama, E. F., and K. R. French, 2010, Luck versus skill in the cross-section of mutual fund returns, Journal of Finance, Vol. 65, pp. 1915-1947.

French, K. R., Dollar cost averaging, Fama/French Forum Videos, Available at https://famaf rench.dimensional.com/videos/dollar-cost-averaging.aspx, 2009.

Hayley, S., Value averaging and how dynamic strategies bias the IRR and modified IRR, Working Paper, Available at (https://papers.ssrn.com/sol3/papers.cfm?abstract_id= 1606347), 2013. 
Does Value Averaging Strategy Improve Investment Performance? Evidence from the Korean Fund Market

Hayley, S., 2014, Hindsight effects in dollar-weighted returns, Journal of Financial and Quantitative Analysis, Vol. 49, pp. 249-269.

Indro, D. C., C. X. Jiang, M. Y. Hu, and W. Y. Lee, 1999, Mutual fund performance: Does fund size matter?, Financial Analysts Journal, Vol. 55, pp. 74-87.

Investment Company Institute, Investment company fact book 59 th edition: A Review of Trends and Activity in the Investment Company Industry, Investment Company Institute, Washington D.C., 2019.

Koh, G., 2006, A Study on the Return and Risk Characteristics of Dollar-Cost Averaging Strategy, Korea Business Review, Vol. 41, pp. 307-329.

Leggio, K. B., and D. Lien, 2001, Does loss aversion explain dollar-cost averaging?, Financial Services Review, Vol. 10, pp. 117-127.

Leggio, K. B., and D. Lien, 2003, Comparing alternative investment strategies using riskadjusted performance measures, Journal of Financial Planning, Vol. 16, pp. 82-86.

Marshall, P. S., 2000, A statistical comparison of value averaging vs. Dollar cost averaging and random investment techniques, Journal of Financial and Strategic Decisions, Vol. 13, pp. 87-99.

Marshall, P. S., 2006, A multi-market, historical comparison of the investment returns of value averaging, dollar cost averaging and random investment techniques, Academy of Accounting and Financial Studies Journal, Vol. 10, pp. 81-98.

Park, Y., and S. Lee, 2010, Does Dollar-Cost-Averaging Strategy Really Outperform Lump-Sum Strategy in the Fund Investment?, Asian Review of Financial Research, Vol. 23, pp. 55-88.

Sharpe, W. F., Investments, 2nd ed., Prentice-Hall, New Jersey, 1981.

Song, Y., 2009, Is Dollar Cost Averaging Superior to Lump Sum?, Financial Planning Review, Vol. 2, pp. 45-73.

Statman, M., 1995, A behavioral framework for dollar-cost averaging, Journal of Portfolio Management, Vol. 3, pp. 70-78.

Thorley, S., 1994, The fallacy of dollar cost averaging, Financial Practice \& Education, Vol. 4, pp. 138-143. 